\title{
Antioxidant Activity of Stryphnodendron rotundifolium Mart. Stem Bark Fraction in an Iron Overload Model
}

\author{
Gerson Javier Torres Salazar ${ }^{1}$, Francisco Junio Dias ${ }^{1}$, Paulo Riceli Vasconcelos Ribeiro ${ }^{2}$, Edy Sousa de Brito ${ }^{2}{ }^{\mathbb{D}}$, \\ Kirley Marques Canuto ${ }^{2}{ }^{(}$, Henrique Douglas Melo Coutinho ${ }^{3}{ }^{(0}$, Jaime Ribeiro-Filho ${ }^{4}{ }^{\oplus}$, Monica Gallo ${ }^{5, *}{ }^{\circ}$, \\ Domenico Montesano $^{6}\left(\mathbb{1}\right.$, Daniele Naviglio ${ }^{7, *}{ }^{\mathbb{D}}$, Gokhan Zengin ${ }^{8}\left(\mathbb{D}\right.$ and José Galberto Martins da Costa ${ }^{1,3}$
}

Citation: Salazar, G.J.T.; Dias, F.J.; Ribeiro, P.R.V.; de Brito, E.S.; Canuto, K.M.; Coutinho, H.D.M.;

Ribeiro-Filho, J.; Gallo, M.;

Montesano, D.; Naviglio, D.; et al.

Antioxidant Activity of

Stryphnodendron rotundifolium Mart. Stem Bark Fraction in an Iron

Overload Model. Foods 2021, 10, 2683.

https://doi.org/10.3390/foods10112683

Academic Editor: Saini Ramesh Kumar

Received: 1 October 2021

Accepted: 1 November 2021

Published: 3 November 2021

Publisher's Note: MDPI stays neutra with regard to jurisdictional claims in published maps and institutional affiliations.

Copyright: (c) 2021 by the authors. Licensee MDPI, Basel, Switzerland. This article is an open access article distributed under the terms and conditions of the Creative Commons Attribution (CC BY) license (https:// creativecommons.org/licenses/by/ $4.0 /)$.
1 Postgraduate Program in Ethnobiology and Nature Conservation, Regional University of Cariri, Coronel Antônio Luíz Street, 1161-Pimenta, Crato 63105-010, Brazil; timotygertor@yahoo.com (G.J.T.S.); junordias195@gmail.com (F.J.D.); galberto.martins@gmail.com (J.G.M.d.C.)

2 Multi-User Laboratory of Natural Products Chemistry, Embrapa Tropical Agroindustry, Sara Mesquita, no 2.270, Neighborhood Planalto do Pici, Fortaleza 60511-110, Brazil; pauloriceli85@gmail.com (P.R.V.R.); edy.brito@embrapa.br (E.S.d.B.); kirley.canuto@embrapa.br (K.M.C.)

3 Postgraduate Program in Biological Chemistry, Regional University of Cariri, Coronel Antônio Luíz Street, 1161-Pimenta, Crato 63105-010, Brazil; hdmcoutinho@gmail.com

4 Laboratory of Investigation in Genetics and Translational Hematology, Gonçalo Moniz Institute (IGM), Oswaldo Cruz Foundation (FIOCRUZ), Waldemar Falcão Street, 121, Candeal, Salvador 40296-710, Brazil; jaimeribeirofilho@gmail.com

5 Department of Molecular Medicine and Medical Biotechnology, University of Naples Federico II, Via Pansini 5, 80131 Naples, Italy

6 Department of Pharmacy, University of Naples Federico II, Via D. Montesano 49, 80131 Naples, Italy; domenico.montesano@unina.it

7 Department of Chemical Sciences, University of Naples Federico II, Via Cintia, 4, 80126 Naples, Italy

8 Department of Biology, Science Faculty, Selcuk University, Campus, 42130 Konya, Turkey; gokhanzengin@selcuk.edu.tr

* Correspondence: mongallo@unina.it (M.G.); naviglio@unina.it (D.N.)

Abstract: Stryphnodendron rotundifolium Mart., popularly known as "barbatimão", is a plant species traditionally used by topical and oral routes for the treatment of infectious and inflammatory diseases. Considering the well-described antioxidant properties of this species, this study investigated the protective effects of its keto-aqueous extract using an in vitro model of iron overload. Phenolic compounds were quantified and identified by Ultra-Performance Liquid Chromatography coupled with quadrupole Time-Of-Flight Electrospray Ionization Mass Spectrometry (UPLC-ESI-qTOF-MS/MS) in positive and negative ions mode analysis. Antioxidant activity was analyzed following the iron-chelating-reducing capacity and deoxyribose degradation (2-DR) protection methods. The analysis identified condensed tannins (54.8 mg catechin/g dry fraction (DF), polyphenols (25 mg gallic acid/g DF), and hydrolyzable tannins (28.8 mg tannic acid/g DF). Among the constituents, prodelphinidin, procyanidin, and prorobinetinidine were isolated and identified. The extract significantly protected 2-DR degradation induced by $\mathrm{Fe}^{2+}$ (72\% protection) or ${ }^{\bullet} \mathrm{OH}$ (43\% protection). The ortho-phenanthroline test revealed $\mathrm{Fe}^{2+}$-chelating and $\mathrm{Fe}^{3+}$-reducing activities of $93 \%$ and $84 \%$, respectively. A preliminary toxicological analysis using Artemia salina revealed mortality below 10\%, at a concentration of $0.25 \mathrm{mg} / \mathrm{mL}$, indicating low toxicity under the present experimental conditions. In conclusion, the findings of the present study indicate that Stryphnodendron rotundifolium is a source of antioxidant compounds with the potential to be used in drug development in the context of iron overload disorders, which remains to be further investigated in vivo.

Keywords: antioxidant activity; free radicals; iron overload; Stryphnodendron rotundifolium; tannins; UPLC-ESI-qTOF-MS/MS 


\section{Introduction}

Stryphnodendron rotundifolium Mart. is a plant species endemic to the Chapada do Araripe, Brazil, popularly known as "barbatimão". The stem bark of this plant is widely used in traditional medicine in the preparation of tinctures, syrups, and teas for the treatment of wounds, ulcers, gastritis, inflammation, and vaginal infections [1,2].

The tannin composition in the bark of Stryphnodendron species ranges from $20 \%$ to $50 \%$ and is potentially responsible for its antioxidant properties [3]. In this context, previous studies have shown that alcoholic extracts obtained from the bark and leaves of $S$. rotundifolium exhibited free radical-scavenging activity and inhibited $\mathrm{Fe}^{2+}$-induced lipid peroxidation in brain homogenates of Wistar rats [4]. Accordingly, consistent evidence has demonstrated that phenolic compounds, including flavonoids and tannins, are crucially responsible for the antioxidant activity of plant-derived natural products [5-7].

Iron accumulation results in tissue damage by promoting the generation of reactive oxygen species (ROS), leading to the oxidation of vital molecules such as proteins, lipids, and DNA. The main clinical conditions associated with iron overload are hereditary hemochromatosis and secondary hemochromatosis. These diseases are characterized by excessive absorption of the mineral by intestinal cells, causing iron overload and tissue accumulation, which leads to organ damage, especially in the liver. Secondary hemochromatosis is commonly related to recurrent transfusion of red blood cells. In this case, iron overload is managed mainly with chelating agents [8-10]. Iron excess may also occur due to iron inhalation in mining and steel welding [11] and associated with transferrin deficiency [12].

With regard to iron homeostasis, the cellular mechanisms responsible for the excretion of this mineral are less developed and effective than those that regulate its absorption and distribution, which can lead to its accumulation in several iron-carrying cells $[13,14]$.

Previous research has demonstrated that many chronic diseases result from an imbalance between ROS generation and the antioxidant mechanisms in the host cells, highlighting the importance of discovering new antioxidant products [15,16]. In addition, consistent evidence has indicated that iron overload contributes to the development of several chronic/degenerative diseases, especially cardiovascular diseases, mainly by inducing oxidative stress mechanisms, highlighting the therapeutic potential of iron-chelating agents. Therefore, the development of in vitro and in vivo assays, capable of accurately evaluating the antioxidant activity and toxicity of plant extracts, represents a significant preliminary step in the search for natural products capable of controlling iron overload disorders $[17,18]$.

The present study reports the extraction and chemical characterization of the tanninrich fraction of S. rotundifolium Mart. (TFSR). The in vitro antioxidant activity of this fraction was investigated under iron and free-radical overload conditions, and its cytotoxicity was assessed using an Artemia salina model.

\section{Materials and Methods}

\subsection{Botanical Material and Extraction Procedure}

Stryphnodendron rotundifolium stem bark samples were collected in the Araripe National Forest, in the municipality of Crato, Ceará, Brazil (coordinates: $07^{\circ} 81^{\prime} \mathrm{S}, 039^{\circ} 28^{\prime} \mathrm{W}$ ). Dr. Maria Arlene Pessoa identified the species, and a voucher specimen was prepared and registered at the Herbarium of the Regional University of Cariri (registry number: 14,074).

A total of $2100 \mathrm{~g}$ of freshly collected barks were dried, crushed, and subjected to fat removal with hexane. Then, hexane was removed from the solid material at $70{ }^{\circ} \mathrm{C}$. Following this process, the material was subjected to exhaustive maceration using a 7:3 acetone-water mixture for $72 \mathrm{~h}$ at room temperature, to avoid interactions between tannins and vegetable proteins, favoring the obtainment of more stable tannins. This procedure was repeated three times as previously described $[19,20]$. The resulting solution was subjected to exhaustive removal of acetone in a rotary evaporator (at $65^{\circ} \mathrm{C}$ and pressure), reducing the volume to one-third of the initial extractive mixture, after which it was concentrated 
in a water bath at $70{ }^{\circ} \mathrm{C}$ for $24 \mathrm{~h}$. The acetone-free concentrated liquid was frozen and subjected to lyophilization, after which the tannic fraction was obtained as an amorphous solid.

\subsection{Phytochemical Prospecting}

Phytochemical analysis was carried out to determine the qualitative composition of secondary metabolites. The presence of phenols, tannins, flavonoids, and alkaloids was analyzed according to a previously described method [21]. According to this method, colorimetric changes or precipitate formation in the fraction solution after the addition of specific reagents are indicative of the presence of the corresponding class of secondary metabolites. The screening of phenolic compounds was performed using $\mathrm{FeCl}_{3}, 1 \%$ methanolic solution, and $1 \mathrm{~N} \mathrm{HCl}, 10 \%(w / v) \mathrm{NaOH}$, while the screening of alkaloids was performed using $5 \%$ $(v / v)$ acetic acid, $10 \%(v / v) \mathrm{NH}_{4} \mathrm{OH}$, chloroform p.a., and Dragendorff's reagent.

\subsection{Quantification of Phenolic Compounds}

\subsubsection{Total Phenolic Content}

The total content of phenolic compounds was determined using a method developed by [22]. A total of $200 \mu \mathrm{L}$ of the fraction aqueous solution $(0.1 \mu \mathrm{g} / \mathrm{mL})$ was added with $600 \mu \mathrm{L}$ of ethanol $(70 \% v / v)$ and $400 \mu \mathrm{L}$ of the Folin-Ciocâlteu reagent $(10 \% v / v)$, and the solution was vigorously shaken. After $5 \mathrm{~min}$, the solution was added with $\mathrm{Na}_{2} \mathrm{CO}_{3}(2800$ $\mu \mathrm{L}, 7.5 \% \mathrm{~m} / \mathrm{v}$ ) and incubated for $20 \mathrm{~min}$ at $45{ }^{\circ} \mathrm{C}$ in the absence of light. The absorbance was measured at $735 \mathrm{~nm}$ using the UV/Vis spectrophotometer (T80 PG Instruments LTD, Wibtoft, Leicestershire, United Kingdom. Gallic acid (GA) was used as a positive control, and the phenolic content was determined by linear regression using calibration curve (5.0 $0.5 \mu \mathrm{g} / \mathrm{mL}$ ), performed in triplicate, and the results expressed in $\mathrm{mg}$ GA/g dry fraction (DF) (linear equation $\left(y=0.1351 x+0.0727, R^{2}=0.9971\right)$.

\subsubsection{Determination of Total Condensed Tannins}

The content of condensed tannins was determined using the vanillin assay, as described by [23], with modifications. An aliquot of $0.5 \mathrm{~mL}$ of the fraction diluted in water $(0.5$ $\mathrm{mg} / \mathrm{mL}$ ) was added with $3 \mathrm{~mL}$ of vanillin $(4 \% v / v$ in methanol) followed by the addition of hydrochloric acid $(1.5 \mathrm{~mL})$. The mixture was shaken and kept at $20^{\circ} \mathrm{C}$ for $15 \mathrm{~min}$ in the absence of light. The absorbance of the mixture was measured at $500 \mathrm{~nm}$ and compared with a calibration curve $(40-5 \mu \mathrm{g} / \mathrm{mL})$ of a catechin aqueous solution. The content was calculated by linear regression of the calibration curve (linear equation $(y=0.0176 x+0.1464$, $\left.R^{2}=0.9843\right)$ ) in triplicate, and the results were expressed in $\mathrm{mg}$ cat/g DF.

\subsubsection{Quantification of Total Hydrolyzable Tannins}

Hydrolyzable tannins were detected according to the method proposed by [24], with modifications. A sample $(0.20 \mathrm{~g})$ of the fraction was extracted with $50 \mathrm{~mL}$ of methanol $(80 \%)$ and then centrifuged at $493 \times g$ for $10 \mathrm{~min}$. After centrifugation, $2 \mathrm{~mL}$ of the fraction was diluted with distilled water and mixed with $5 \mathrm{~mL}$ of a $\mathrm{KIO}_{3}$ solution $(2.5 \% \mathrm{~m} / \mathrm{v})$ in water. The resulting solution was heated to $30{ }^{\circ} \mathrm{C}$ for $7 \mathrm{~min}{ }^{\circ} \mathrm{C}$, and, after cooling, the absorbance was read at $550 \mathrm{~nm}$. The content was calculated by linear regression through a calibration curve (linear equation $\left(y=1.9636 x+0.0724, R^{2}=0.9818\right)$ of tannic acid (tac) $(0.4-0.1 \mathrm{mg} / \mathrm{mL})$ in triplicate, and the results were expressed in $\mathrm{mg}$ tac $/ \mathrm{g} \mathrm{DF}$.

\subsection{UPLC-ESI-qTOF-MS/MS}

These analyses were performed using an Acquity UPLC (Waters Corporation, Milford, MA, USA) system coupled to a Xevo qTOF mass spectrometer (Q-TOF, Waters). Separations were performed on a C18 column (Waters Acquity ${ }^{\circledR}$ UPLC C18; $150 \mathrm{~mm} \times 2.1 \mathrm{~mm}, 1.7 \mu \mathrm{m}$ ). For metabolic fingerprinting, a $2 \mu \mathrm{L}$ aliquot of the fraction was subjected to UPLC analysis using an exploratory gradient with a mobile phase comprising deionized water (A) and acetonitrile (B), both containing formic acid $0.1 \% v / v$. The sample was subjected to the 
exploratory gradient as follows: $2-95 \%$ for $15 \mathrm{~min}$, at a flow rate of $500 \mu \mathrm{L} \cdot \mathrm{min}^{-1}$. Ionization was performed with electrospray ionization (ESI) source in negative and positive ion modes, in the range of 110-1200 Da. The optimized instrumental parameters were as follows: capillary voltage of $-2800 \mathrm{~V}$, cone voltage of $-40 \mathrm{~V}$, source temperature of $120^{\circ} \mathrm{C}$, desolvation temperature of $330{ }^{\circ} \mathrm{C}$, flow cone gas of $20 \mathrm{~L} \cdot \mathrm{h}^{-1}$, desolvation gas flow at $600 \mathrm{~L} \cdot \mathrm{h}^{-1}$, and microchannel plate (MCP) detector voltage of $-1900 \mathrm{~V}$. The mode of acquisition was MS/MS, and the system was controlled using MassLynx 4.1 software (Waters Corporation, Milford, MA, USA).

\subsection{In Vitro Antioxidant Activity Analysis}

\subsection{1. $\mathrm{Fe}^{2+}$-Chelating Activity and $\mathrm{Fe}^{3+}$-Reducing Power as a Function of Time}

In these experiments, the protective activity of the fraction was evaluated in reactive mixtures containing $\mathrm{Fe}^{2+}$ at the concentration of $100 \mu \mathrm{M}$, which is equivalent to $5.58 \mu \mathrm{g} / \mathrm{mL}$. Since normal iron concentration in the blood ranges from $0.65 \mu \mathrm{g} / \mathrm{mL}$ to $1.7 \mu \mathrm{g} / \mathrm{mL}$ and the maximum concentration of iron transported by transferrin (tf) in blood is in the range of $2.5 \mu \mathrm{g} / \mathrm{mL}$ to $4.5 \mu \mathrm{g} / \mathrm{mL}$ [25-28], the protocol follow was used as an in vitro model of $\mathrm{Fe}^{2+}$ overload.

The $\mathrm{Fe}^{2+-}$ chelating and $\mathrm{Fe}^{3+-}$ reducing capacity of the fraction were evaluated through the $o$-phenanthroline (o-phe) assay, as described by the method of [29], with some modifications. Samples were separately added with $\mathrm{Fe}^{2+}$ and $\mathrm{Fe}^{3+}$ through the addition of $\mathrm{FeSO}_{4}$ and $\mathrm{FeCl}_{3}(1 \mathrm{mM})$, respectively, in a dark and refrigerated environment. Then, aliquots of $40 \mu \mathrm{L}$ were extracted at times $0.5,2.5,5,10,20,30,45,60,75$, and $90 \mathrm{~min}$ and reacted with $o$-phe $(300 \mu \mathrm{M})$ in $\mathrm{H}_{2} \mathrm{O}$ milli-Q and Tris- $\mathrm{HCl}(0.1 \mathrm{M}, \mathrm{pH}$ 7.4). At the end of this procedure, the samples were obtained at final concentrations of $0.2,0.1$, and $0.05 \mathrm{mg} / \mathrm{mL}$, and $\mathrm{Fe}^{2+}$ and $\mathrm{Fe}^{3+}$ were obtained both at $100 \mu \mathrm{M}$. The readings were carried out at $510 \mathrm{~nm}$. Experimental controls were obtained by replacing aliquots of the samples with milli-Q water. To evaluate the stability of the chelates, ascorbic acid (at the final concentration of 0.005 $\mathrm{M}$ ) was added to each reacting system (at the timepoint of $90 \mathrm{~min}$ ), and the readings were performed $15 \mathrm{~min}$ later. The results are representative of three independent experiments $(n$ =3) performed in duplicate.

The $\mathrm{Fe}^{2+}$-chelating activity (FCA) and $\mathrm{Fe}^{3+}$-reducing power (FRP) were expressed as a percentage of the control, as represented by the Equations (1) and (2), respectively.

$$
\begin{aligned}
& \operatorname{FCA}(\%) t_{\text {minutes }}=\frac{\left(\mathrm{Abs}_{\text {controle- }-\mathrm{Fe}^{2+}}-\left(\mathrm{Abs}_{\text {fraction- }} \mathrm{Fe}^{2+}-\mathrm{Abs}_{\text {fraction-blank- }} \mathrm{Fe}^{2+}\right)\right) \times 100}{\mathrm{Abs}_{\text {controle }-\mathrm{Fe}^{2+}}} \\
& \operatorname{FRP}(\%) t_{\text {minutes }}=\frac{\left.\left(\mathrm{Abs}_{\text {fraction }-\mathrm{Fe}^{3+}}-\mathrm{Abs}_{\text {fraction-blank }-\mathrm{Fe}^{3+}}\right)-\mathrm{Abs}_{\text {control- } \mathrm{Fe}^{3+}}\right) \times 100}{\mathrm{Abs}_{\text {controle }-\mathrm{Fe}^{2+}}}
\end{aligned}
$$

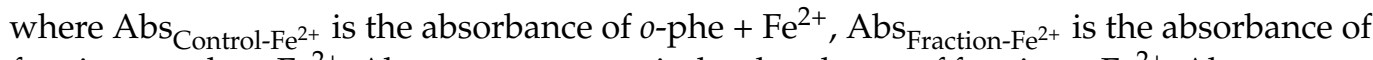
fraction $+o$-phe $+\mathrm{Fe}^{2+}, \mathrm{Abs}_{\text {Fraction-blank-Fe }}{ }^{2+}$ is the absorbance of fraction $+\mathrm{Fe}^{2+}, \mathrm{Abs}_{\mathrm{Control}-\mathrm{Fe}^{3+}}$

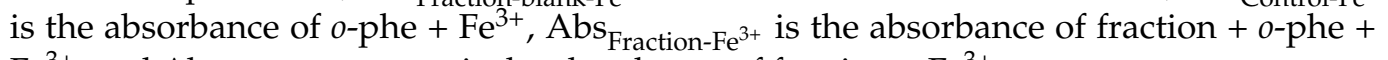
$\mathrm{Fe}^{3+}$, and $\mathrm{Abs}_{\text {Fraction-blank-Fe }}{ }^{3+}$ is the absorbance of fraction $+\mathrm{Fe}^{3+}$.

\subsubsection{Deoxyribose Oxidative Degradation Assay}

The ${ }^{\bullet} \mathrm{OH}$ radical-scavenging activity was investigated according to the ability of the fraction to inhibit the degradation of 2-deoxyribose (2-DR) in vitro, following the method used by [30], with adaptations. Briefly, $1.5 \mathrm{mM}$ 2-DR was incubated with $50 \mathrm{mM}$ potassium phosphate buffer ( $\mathrm{pH}$ 7.4) at room temperature for $20 \mathrm{~min}$ in the following pro-oxidant systems: (i) $0.05 \mathrm{mM} \mathrm{FeSO}_{4}$ and (ii) $0.5 \mathrm{mM} \mathrm{H}_{2} \mathrm{O}_{2}+0.05 \mathrm{mM} \mathrm{FeSO}_{4}$ (Fenton reaction); then, it was incubated at $37{ }^{\circ} \mathrm{C}$ for $60 \mathrm{~min}$, in the absence or presence of the variable concentrations of the fractions $(0.2,0.1$, and $0.075 \mathrm{mg} / \mathrm{mL})$. Following this step, $750 \mu \mathrm{L}$ of Trichloroacetic Acid (TCA) (2.8\%) and $750 \mu \mathrm{L}$ of Thiobarbituric Acid (TBA) $(0.8 \%)$ were added to all samples, before incubating for $20 \mathrm{~min}$ at $100^{\circ} \mathrm{C}$. The readings were carried out 
at $532 \mathrm{~nm}$, and the results are expressed as a percentage of inhibition of 2-DR degradation relative to the negative controls according to Equation (3).

$$
\operatorname{Inhibition}(\%)=\frac{\left[\left(\mathrm{Abs}_{\text {control }}-\mathrm{Abs}_{\text {blank }}\right)\right] \times 100 \%}{\mathrm{Abs}_{\text {control }}}
$$

where $\mathrm{Abs}_{\mathrm{Control}}$ is the Absorbance of 2-DR + pro-oxidant, $\mathrm{Abs}_{\text {Fraction }}$ is the absorbance of 2-DR + pro-oxidant + fraction, and $\mathrm{Abs}_{\text {Blank }}$ is the absorbance of pro-oxidant + fraction.

Of note, the Fenton reaction was performed with $50 \mu \mathrm{M} \mathrm{Fe}^{2+}$, which is equivalent to $2.79 \mu \mathrm{g} / \mathrm{mL}$. The results are representative of four independent experiments $(n=4)$ performed in duplicate.

\subsubsection{Analysis of the Mechanism Underlying the Inhibition of 2-DR Degradation}

An assay based on the variation of the 2-DR concentration $(1.5 \mathrm{mM}, 1.75 \mathrm{mM}$, and 2.0 $\mathrm{mM})$ was used to determine the antioxidant mechanism of the fraction $\left(\mathrm{Fe}^{2+}\right.$ chelating or - $\mathrm{OH}$ scavenging). The oxidative degradation of 2-DR was obtained via the reaction of 0.5 $\mathrm{mM} \mathrm{H}_{2} \mathrm{O}_{2}$ with $0.05 \mathrm{mM} \mathrm{FeSO}_{4}$, which results in the generation of the ${ }^{\bullet} \mathrm{OH}$ radical. The tests were performed three $(n=3)$ times in duplicate for each concentration of 2-DR (1.5 $\mathrm{mM}, 1.75, \mathrm{mM}$, and $2.0 \mathrm{mM}$ ). The results were expressed as a percentage inhibition of 2-DR degradation according to Equation (4) [31].

$$
\text { Inhibition }(\%)=\frac{\left[\mathrm{Abs}_{\left(\mathrm{H} 2 \mathrm{O} 2+\mathrm{Fe}^{2+}\right) \text { control }}-\left(\mathrm{Abs}_{\text {fraction }}-\mathrm{Abs}_{\text {blank }}\right)\right] \times 100 \%}{\mathrm{Abs}_{\left(\mathrm{H}_{2} \mathrm{O} 2+\mathrm{Fe}^{2+}\right) \text { control }}}
$$

where $\mathrm{Abs}_{\left(\mathrm{H}_{2} \mathrm{O}_{2}+\mathrm{Fe}^{2+}\right) \text { Control }}$ is the absorbance of 2-DR $+\left(\mathrm{H}_{2} \mathrm{O}_{2}+\mathrm{Fe}^{2+}\right), \mathrm{Abs}_{\text {Fraction }}$ is the absorbance of 2-DR $+\left(\mathrm{H}_{2} \mathrm{O}_{2}+\mathrm{Fe}^{2+}\right)+$ fraction, and $\mathrm{Abs}_{\text {Blank }}$ is the absorbance of $\left(\mathrm{H}_{2} \mathrm{O}_{2}+\right.$ $\left.\mathrm{Fe}^{2+}\right)+$ fraction.

\subsection{In Vivo Toxicity Analysis}

Saline solution (36.2 g/L, pH 7.0-9.0) was prepared by adding $72.4 \mathrm{~g}$ of sea salt in $2 \mathrm{~L}$ of distilled water. A total of $200 \mathrm{mg}$ of Artemia Salina eggs were placed to hatch in $400 \mathrm{~mL}$ of saline solution for $24 \mathrm{~h}$ under continuous aeration and exposure to light. To determine the in vivo toxicity of the fraction, 10 larvae were placed in $10 \mathrm{~mL}$ of a solution containing the fraction at increasing concentrations $(0.001$ to $0.250 \mathrm{mg} / \mathrm{mL})$. The mortality was analyzed $24 \mathrm{~h}$ after treatments. The tests were performed in triplicate [32].

\subsection{Statistical Analysis}

The data of the antioxidant and toxicity assays, as well as those of chemical quantification, were expressed as the means \pm Standard Error of Mean (SEM) of at least three experiments. The antioxidant assays were analyzed by one-way analysis of variance (ANOVA), followed by Tukey's post hoc test for multiple comparisons of data with normal distribution and similar standard deviation, using GraphPad Prism version 6.0. The UPLC/MS data were expressed as the means \pm SEM of three determinations and analyzed by ANOVA followed by Tukey's test. Statistical significance was considered when $p<0.05$.

\section{Results and Discussion}

The tannin-rich fraction from Stryphnodendron rotundifolium Mart. (TFSR) was obtained as a reddish solid, characteristic of proanthocyanidins. The acetone-water (7:3) extraction presented a yield of $38.8 \%$. The phytochemical characterization demonstrated the presence of secondary metabolites such as polyphenols, flavonoids, leucoanthocyanidins, aurones, chalcones, catechins, and hydrolyzable and condensed tannins. In particular, the UPLCESI-qTOF-MS/MS profile revealed the presence of type B proanthocyanidins, including prodelphinidins (monomers, dimers, and trimers), procyanidins, and prorobinetidins previously reported in other species of the same genus $[5,33,34]$. 
The concentration of total phenols was determined in $25.02 \pm 0.67 \mathrm{mg}$ gallic acid $/ \mathrm{g}$ DF. The quantification of condensed tannins was $54.83 \pm 2.30 \mathrm{mg}$ catechin equivalent $/ \mathrm{g}$ DF, corresponding to the main type of component in the sample. In addition, the concentration of hydrolyzable tannins was $28.84 \pm 2.21 \mathrm{mg}$ tannic acid/g DF, confirming this class of components as the second most abundant in the sample. In fact, extractive mixtures containing acetone favor the extraction of condensed tannins formed by monomeric units of the catechin type flavan-3-ols, to the detriment of hydrolyzable tannins [19].

The chemical constituents of the TFSR were identified using the UPLC-ESI-qTOFMS/MS technique, by interpreting their MS and MS/MS spectra, determined by QTOFMS and compared with the literature data and the open-access mass spectrum database SciFinder. The chromatogram and phenolic profile are shown in Figure 1 and Table 1, respectively.

A total of 17 peaks were identified, revealing the presence of compounds belonging to corresponding to two main classes of metabolites: phenolic acids and tannins. The compounds were eluted in a noticeably short period of time $(6.9 \mathrm{~min})$. Together, the retention time and the number of peaks observed in the present analysis indicate that UPLC is an efficient separation technique. 


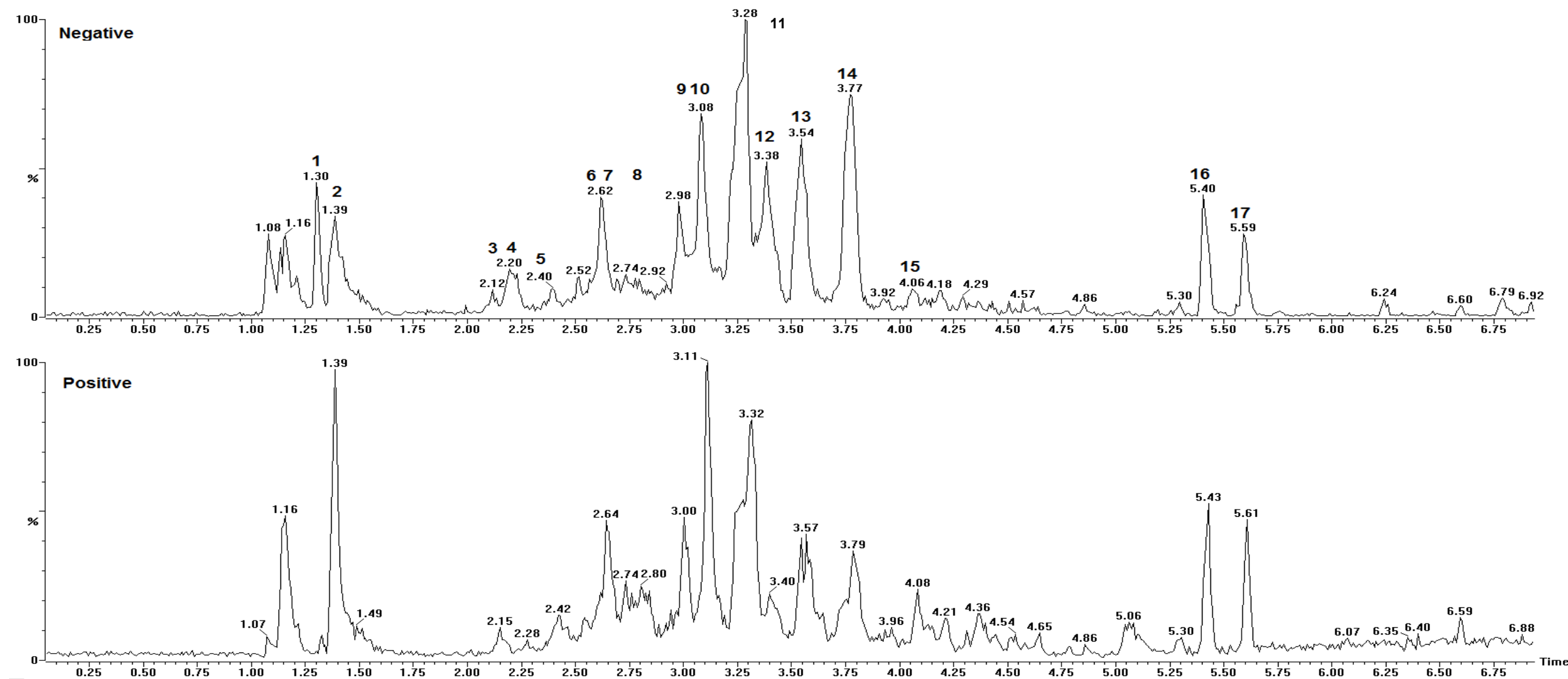

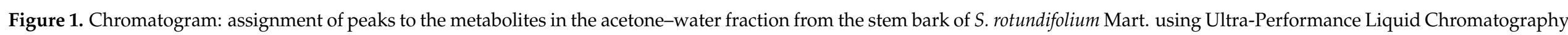

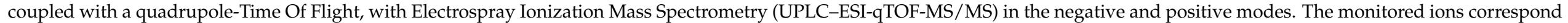

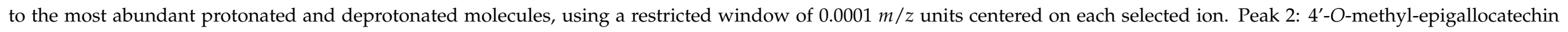

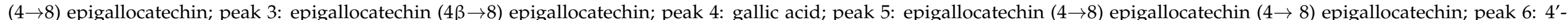

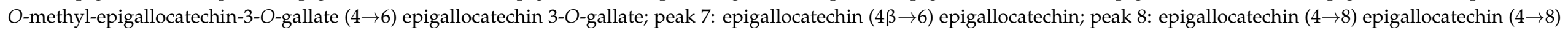

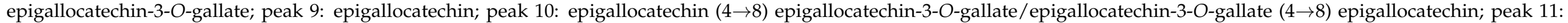
robinetinidol-4'-O-methyl $(4 \rightarrow 8)$ epigallocatechin; peak 12: C-hexosyl-O-pentosyl-5,7-dihydroxychromone isomer; peak 13: procyanidin prodelphinidin type B. 
Table 1. Identification of TFSR phenolic compounds using UPLC-ESI-qTOF-MS/MS in the negative and positive modes.

\begin{tabular}{|c|c|c|c|c|c|c|c|c|c|c|}
\hline $\begin{array}{l}\text { Peak } \\
\text { No. }\end{array}$ & $\underset{(\min )}{\mathbf{R t}}$ & $\begin{array}{c}{[\mathrm{M}+\mathrm{H}]^{+}} \\
\text {Obs }\end{array}$ & $\underset{\text { Obs }}{[\mathrm{M}]^{-}}$ & $\begin{array}{l}\text { Empirical } \\
\text { Formula } \\
{[\mathbf{M}-\mathbf{H}]^{-}}\end{array}$ & Ion Products (MS/MS) & $\begin{array}{c}\text { Empirical } \\
\text { Formula }[\mathrm{M}+\mathrm{H}]^{+}\end{array}$ & $\begin{array}{l}\text { Empirical Formula } \\
\text { M/MM (g.mol-1) }\end{array}$ & $\begin{array}{l}\Delta^{1} \\
\text { (Error) }\end{array}$ & Structure Name & Ref. \\
\hline 1 & 1.30 & 383.1159 & no $^{2}$ & - & 203.0517 & $\mathrm{C}_{21} \mathrm{H}_{19} \mathrm{O}_{7}$ & & -2.3 & Unknown & - \\
\hline 2 & 1.39 & 625.5280 & 623.1370 & $\mathrm{C}_{31} \mathrm{H}_{27} \mathrm{O}_{14}$ & $125.0226,169.0148,305.0661$ & $\mathrm{C}_{31} \mathrm{H}_{29} \mathrm{O}_{14}$ & $\mathrm{C}_{31} \mathrm{H}_{28} \mathrm{O}_{14} / 624.5603$ & 3.7 & $\begin{array}{l}\text { 4'-O-methyl-epigallocatechin }(4 \rightarrow 8) \\
\text { epigallocatechin }\end{array}$ & [33] \\
\hline 3 & 2.15 & 611.1428 & 609.1245 & $\mathrm{C}_{30} \mathrm{H}_{25} \mathrm{O}_{14}$ & $\begin{array}{c}425.0808,299.0632,287.0573 \\
263.0517,179.0361\end{array}$ & $\mathrm{C}_{30} \mathrm{H}_{27} \mathrm{O}_{14}$ & $\mathrm{C}_{30} \mathrm{H}_{26} \mathrm{O}_{14} / 610.494$ & 4.4 & $\begin{array}{l}\text { Epigallocatechin }(4 \beta \rightarrow 8) \\
\text { epigallocatechin }\end{array}$ & {$[5,33-35]$} \\
\hline 4 & 2.20 & 171.0300 & 169.0138 & $\mathrm{C}_{7} \mathrm{H}_{5} \mathrm{O}_{5}$ & - & $\mathrm{C}_{7} \mathrm{H}_{7} \mathrm{O}_{5}$ & $\mathrm{C}_{7} \mathrm{H}_{6} \mathrm{O}_{5} / 170.113$ & 4.1 & Gallic acid $^{3}$ & {$[5,35,36]$} \\
\hline 5 & 2.42 & 915.2008 & 913.1827 & $\mathrm{C}_{45} \mathrm{H}_{37} \mathrm{O}_{21}$ & $\begin{array}{c}\text { 611.1431, 425.0869, } 287.0597 \\
263.0562,179.0362\end{array}$ & $\mathrm{C}_{45} \mathrm{H}_{39} \mathrm{O}_{21}$ & $\mathrm{C}_{45} \mathrm{H}_{38} \mathrm{O}_{21} / 914.733$ & 2.6 & $\begin{array}{l}\text { Epigallocatechin }(4 \rightarrow 8) \\
\text { epigallocatechin }(4 \rightarrow 8) \\
\text { epigallocatechin }\end{array}$ & [5] \\
\hline 6 & 2.62 & 929.7240 & 927.2041 & $\mathrm{C}_{45} \mathrm{H}_{35} \mathrm{O}_{22}$ & $\begin{array}{c}761.1112,423.0788,305.0630 \\
125.0252\end{array}$ & - & $\mathrm{C}_{45} \mathrm{H}_{36} \mathrm{O}_{22} / 928.311$ & 0.2 & $\begin{array}{c}\text { 4'-O-methyl-epigallocatechin-3-O- } \\
\text { gallate }(4 \rightarrow 6) \text { epigallocatechin } \\
\text { 3-O-gallate }\end{array}$ & [33] \\
\hline 7 & 2.64 & 611.1406 & 609.1224 & $\mathrm{C}_{30} \mathrm{H}_{25} \mathrm{O}_{14}$ & $\begin{array}{c}425.0943,287.0575,263.0571 \\
179.0337 \\
\end{array}$ & $\mathrm{C}_{30} \mathrm{H}_{27} \mathrm{O}_{14}$ & $\mathrm{C}_{30} \mathrm{H}_{26} \mathrm{O}_{14} / 610.494$ & 0.8 & $\begin{array}{l}\text { Epigallocatechin }(4 \beta \rightarrow 6) \\
\text { epigallocatechin }\end{array}$ & {$[5,34,35]$} \\
\hline 8 & 2.80 & 1067.2070 & 1065.1937 & $\mathrm{C}_{52} \mathrm{H}_{41} \mathrm{O}_{25}$ & $\begin{array}{l}915.2032,611.1549,425.0953 \\
287.0670,263.0620,179.0453\end{array}$ & $\mathrm{C}_{52} \mathrm{H}_{43} \mathrm{O}_{25}$ & $\mathrm{C}_{52} \mathrm{H}_{42} \mathrm{O}_{25} / 1066.831$ & -2.2 & $\begin{array}{c}\text { Epigallocatechin }(4 \rightarrow 8) \\
\text { epigallocatechin }(4 \rightarrow 8) \\
\text { epigallocatechin-3-O-gallate }\end{array}$ & [7] \\
\hline 9 & 3.00 & 307.0824 & 305.0664 & $\mathrm{C}_{15} \mathrm{H}_{13} \mathrm{O}_{7}$ & $195.0573,177.0488,163.0406$ & $\mathrm{C}_{15} \mathrm{H}_{15} \mathrm{O}_{7}$ & $\mathrm{C}_{15} \mathrm{H}_{14} \mathrm{O}_{7} / 306.255$ & 2.0 & Epigallocatechin & {$[5,33,35]$} \\
\hline 11 & 3.28 & 609.5290 & 607.1412 & $\mathrm{C}_{31} \mathrm{H}_{27} \mathrm{O}_{13}$ & $485.1264,319.0786,287.0568$ & $\mathrm{C}_{31} \mathrm{H}_{29} \mathrm{O}_{13}$ & $\mathrm{C}_{31} \mathrm{H}_{28} \mathrm{O}_{13} / 608.5451$ & 1.4 & $\begin{array}{l}\text { Robinetinidol-4'-O-methyl }(4 \rightarrow 8) \\
\text { epigallocatechin }\end{array}$ & {$[34,35]$} \\
\hline 12 & 3.32 & 487.1447 & 485.1295 & $\mathrm{C}_{21} \mathrm{H}_{25} \mathrm{O}_{13}$ & $\begin{array}{c}355.1012,319.0728,289.0634 \\
259.0592\end{array}$ & $\mathrm{C}_{21} \mathrm{H}_{27} \mathrm{O}_{13}$ & $\begin{array}{c}\mathrm{C}_{21} \mathrm{H}_{26} \mathrm{O}_{13} / \\
486.405\end{array}$ & -1.0 & $\begin{array}{l}\text { C-hexosyl-O-pentosyl-5,7- } \\
\text { dihydroxychromone } \\
\text { isomer }\end{array}$ & [5] \\
\hline 13 & 3.57 & 595.1460 & 593.1277 & $\mathrm{C}_{30} \mathrm{H}_{25} \mathrm{O}_{13}$ & $427.0926,307.0875,289.0704$ & $\mathrm{C}_{30} \mathrm{H}_{27} \mathrm{O}_{13}$ & $\mathrm{C}_{30} \mathrm{H}_{26} \mathrm{O}_{13} / 594.495$ & 1.3 & Procyanidin prodelphinidin type B & [5] \\
\hline 14 & 3.79 & 623.1767 & no $^{2}$ & - & $423.1066,287.0533$ & $\mathrm{C}_{32} \mathrm{H}_{31} \mathrm{O}_{13}$ & - & 0.3 & Unknown & - \\
\hline 15 & 4.08 & 623.1779 & no $^{2}$ & - & $423.1018,287.0552$ & $\mathrm{C}_{32} \mathrm{H}_{31} \mathrm{O}_{13}$ & - & 2.2 & Unknown & - \\
\hline 16 & 5.43 & 677.2097 & no $^{2}$ & - & $\begin{array}{c}545.1690,367.1169,235.0579 \\
191.0706\end{array}$ & $\mathrm{C}_{32} \mathrm{H}_{37} \mathrm{O}_{16}$ & - & 2.2 & Unknown & [5] \\
\hline 17 & 5.60 & 707.2196 & no $^{2}$ & - & $\begin{array}{c}575.1804,367.0898,236.0611 \\
221.0834\end{array}$ & $\mathrm{C}_{33} \mathrm{H}_{39} \mathrm{O}_{17}$ & - & 1.3 & Unknown & \\
\hline
\end{tabular}

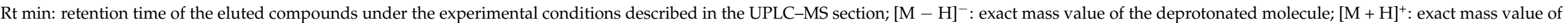

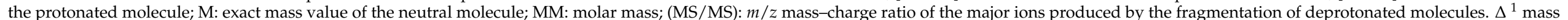

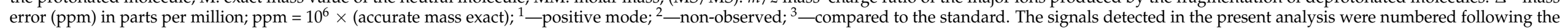
elution order (retention time) 
According to our analysis, peaks 4 and 9 exhibited protonated ions in $\mathrm{m} / z 171.0300$ and 307.0824, respectively, which is compatible with the corresponding molecular formulas $\mathrm{C}_{7} \mathrm{H}_{6} \mathrm{O}_{5}$ and $\mathrm{C}_{15} \mathrm{H}_{14} \mathrm{O}_{7}$, as their fragmentation profiles are compatible with the reported for $S$. adstringens $[5,33,35]$. The fragmentation pattern id compatible with the mechanistic pathway of retro-Diels-Alder (RDA) reactions and the different heterocyclic cleavage of the $\mathrm{C}$ ring (HRF-heterocyclic fission) (Figure 2). In addition, the occurrence of dehydration was crucial for the identification of peak 9 epigallocatechin (EGC) [37].

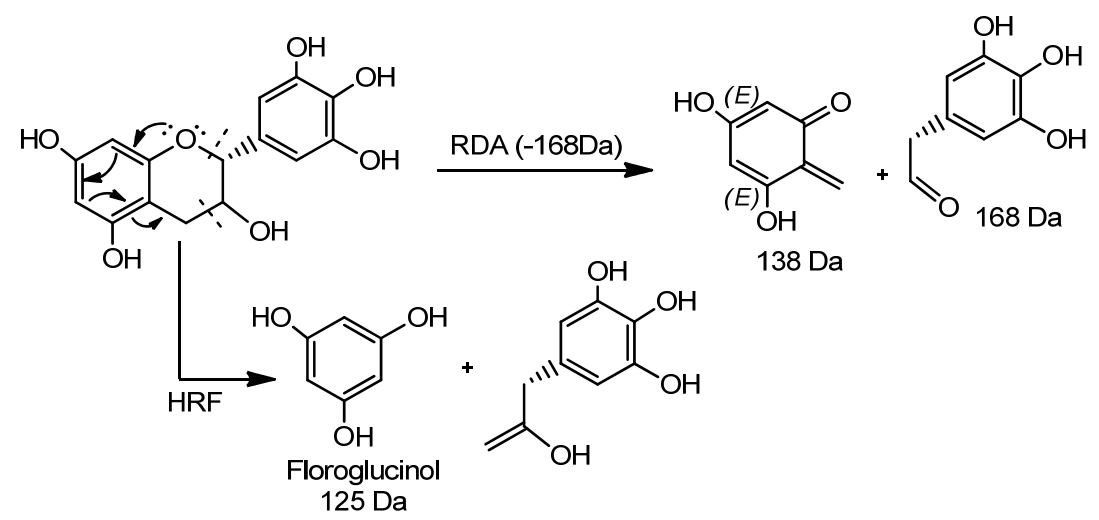

Figure 2. Mechanistic pathways of RDA reactions and heterocyclic cleavage of the Heterocyclic Fission (HRF) C ring.

The protonated ions at $m / z 625.5280$ (peak 2), 611.1428 (peak 3), 929.7240 (peak 6), 611.1406 (peak 7), 763.1538 (peak 10), 609.5290 (peak 11), and 595.1460 (peak 13), corresponding respectively to $\mathrm{C}_{31} \mathrm{H}_{28} \mathrm{O}_{14}, \mathrm{C}_{30} \mathrm{H}_{26} \mathrm{O}_{14}, \mathrm{C}_{45} \mathrm{H}_{36} \mathrm{O}_{22}, \mathrm{C}_{30} \mathrm{H}_{68} \mathrm{O}_{14}, \mathrm{C}_{37} \mathrm{H}_{30} \mathrm{O}_{18}$, $\mathrm{C}_{31} \mathrm{H}_{28} \mathrm{O}_{13}$, and $\mathrm{C}_{30} \mathrm{H}_{26} \mathrm{O}_{13}$, were characterized as type $\mathrm{B}$ dimeric proanthocyanidins and type B dimeric proanthocyanidins with 3-O-galloyl in epigallocatechin (EGC) subunits.

The spectral analysis of peaks 2, 3-8, 10, 11, and 13 revealed fragmentation ions at $m / z 319,307,305,289$, and 287, produced from the generation of quinone and quinone methide with losses of $(110,125,181,318) u, 289 u,(319,457,471,153) u, 289 u,(305,609$, 761) $u$, and $\mathrm{H}_{2} \mathrm{O}$ molecules, consistent with prodelphinidin (PDE), procyanidin (PCY), and prorobinetinidine (PRO). Thus, the common losses due to RDA reactions of 168 and 152 $\mathrm{Da}$, as well as the heterocyclic cleavage reactions of the C HRF $125 \mathrm{Da}$ ring (floroglucinol), suggest the presence of PDE, PRO, and PCY.

Pseudomolecular ion products at $m / z 425\left[\mathrm{M}+\mathrm{H}^{+}-168-\mathrm{H}_{2} \mathrm{O}\right]^{+},\left[\mathrm{M}+2 \mathrm{H}^{+}-305-\right.$ $\left.168-\mathrm{H}_{2} \mathrm{O}\right]^{+},\left[\mathrm{M}+2 \mathrm{H}^{+}-457-168-\mathrm{H}_{2} \mathrm{O}\right]^{+}$resulting from RDA reactions and excisions of 305 EGC and 457 gallate epigallocatechin (EGCG) were observed for peaks 3, 5, 7, and 8. An ion at $m / z 427\left[\mathrm{M}+\mathrm{H}^{+}-168\right]^{+}$was observed for metabolite 13 . The ions at $m / z 485$ [M $\left.+\mathrm{H}^{+}-153-125\right]^{+}$and $\left[\mathrm{M}+2 \mathrm{H}^{+}-125\right]^{+}$resulted from the excisions of the galloyl (153 $\mathrm{Da})$ and floroglucinol (125 Da) groups, respectively, corresponding to peaks 10 and 11 . Of note, six possible isomers were proposed for peak 10 . The ion at $m / z 423\left[\mathrm{M}+2 \mathrm{H}^{+}-169-\right.$ $168-170]^{+}$was associated with peak 6 , such that the $169 \mathrm{Da}$ fragment was associated with the loss of an O-gallate group, in which the $168 \mathrm{Da}$ fragment corresponds to the loss of the 4-O'-methyl-3,5-di-hydroxyl-benzaldehyde portion through heterocyclic cleavage of the C ring. The $170 \mathrm{Da}$ fragment was associated with the loss of a gallic acid unit. Together, these findings suggest the presence of dimeric/trimeric PDE, in addition to PCY and dimeric $\mathrm{PRO}$ in the phenolic fraction under investigation, whose spectral profiles are compatible with the literature data [5,7,33-35].

The type B prodelphinidin trimer shown in peak 5 was identified as three EGC units exhibiting the protonated ion at $m / z$ 915.2008, which corresponds to $\mathrm{C}_{45} \mathrm{H}_{38} \mathrm{O}_{21}$, as also reported in S. adstringens [5]. On the other hand, the type B prodelphinidin trimer in peak 8, consisting of two units of EGC and one EGCG unit that exhibited the protonated ion at $m / z$ 1066.2070, corresponds to $\mathrm{C}_{42} \mathrm{H}_{42} \mathrm{O}_{25}$, as previously reported in Myrica yubra Sieb 
\& Zucc [7]. Of note, proanthocyanidin ions larger than trimers were not identified, since these experiments were recorded in a 110-1200 $\mathrm{Da} m / z$ window.

The characteristic of peak 12 is compatible with the structure of chromonic compounds [38]. Accordingly, its protonated ion presented a precise mass loss at $m / z$ 487.1447, corresponding to $\mathrm{C}_{21} \mathrm{H}_{26} \mathrm{O}_{13}$. The fragmentation of ions at $m / z 487$ produced an ion at $m / z$ $355[\mathrm{M}+\mathrm{H}-132]^{+}$suggesting an O-pentosyl substitute in the structure, at $m / z 319[\mathrm{M}+$ $\mathrm{H}-168]^{+}$. Thus, peak 12 was identified as C-hexosyl O-pentosyl 5, 7-dihydroxychromone, and its spectral data are comparable to the data reported in the literature [5].

In synthesis, the UPLC-MS analysis showed the predominance of type-B proanthocyanidins (PA) with $\mathrm{C}_{4} \rightarrow \mathrm{C}_{8}$ and $\mathrm{C}_{4} \rightarrow \mathrm{C}_{6}$ interflavanic bonds in the tannin-rich fraction of S. rotundifolium.

The molecular structures of compounds (Figure 3) were designed using the Chem Draw Ultra 12.0.2.1076.lnk program (Licensed to Mulder X-Filer 875-317589-4732. 19862010 CambridgeSol).<smiles>c1ccc(C2CCc3ccccc3O2)cc1</smiles>

Ring system numbering for flavonoids and flavan-3-ol

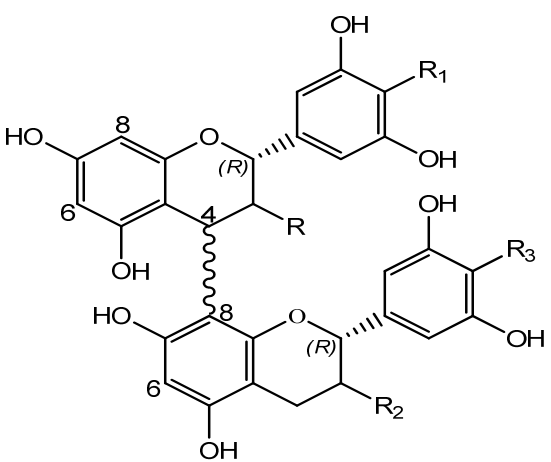

$$
\begin{aligned}
& \text { Peak Rt } \\
& \begin{array}{lllll}
2 & 1.39 & 4 & 4 &
\end{array} \\
& 3 \quad 2.15 \quad 4 \Omega \sim 8 \quad \cdots 11 \mathrm{OH} \\
& 6 \quad 2.62 \quad 4 \text { …111116 } \\
& 7 \quad 2.64
\end{aligned}
$$

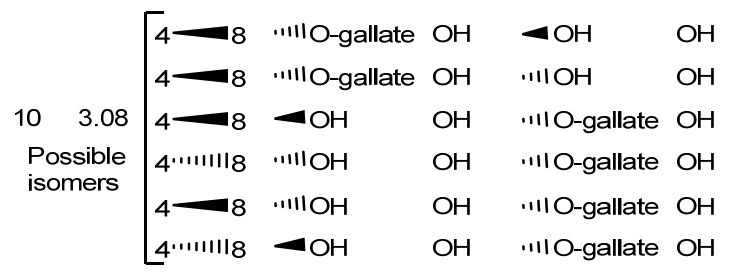

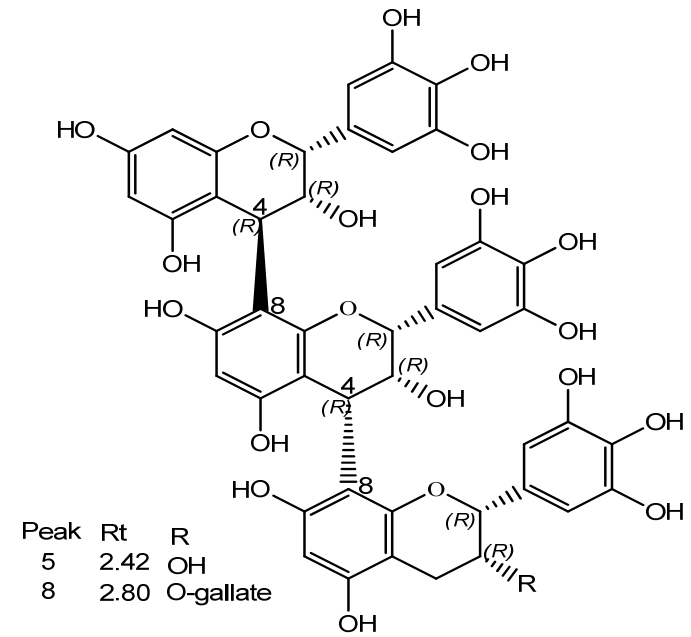

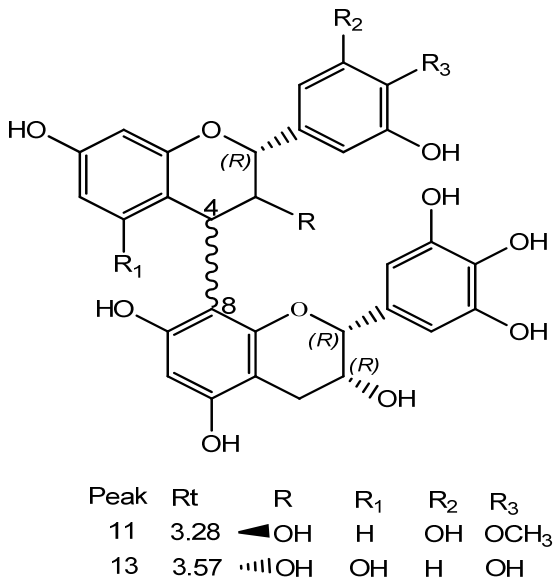

Figure 3. Molecular structures of the metabolites identified in the tannic fraction of Stryphnodendron rotundifolium Mart., (TFSF). 
The findings of the present study indicate that the phenolic composition of S. rotundifolium is characterized by a remarkable presence of type B proanthocyanidins, a group of compounds with demonstrated antioxidant activity, which may, therefore, play important roles in health maintenance and minimization of disease onset and progression [2,39].

The $\mathrm{Fe}^{2+}$-chelating activity and $\mathrm{Fe}^{3+}$-reducing power of TFSR, as a function of time and concentration, were analyzed using the $o$-phe assay. As shown in Table 2, the fraction was effective in chelating $\mathrm{Fe}^{2+}$ at all concentrations and timepoints evaluated in this study. At the highest concentration $(0.200 \mathrm{mg} / \mathrm{mL})$, the activity varied over time ( 0.5 to 90 $\mathrm{min})$, reaching an average $\mathrm{Fe}^{2+}$-chelating rate of $93 \%$. For the lowest concentration $(0.05$ $\mathrm{mg} / \mathrm{mL}$ ), an average value of $77 \%$ was found. The fraction, at the concentrations analyzed, reached maximum activity at $45 \mathrm{~min}$. Importantly, there was no significant difference in the chelating activity at different timepoints when considering the same concentration. However, a significant difference was observed between the $\mathrm{Fe}^{2+}$-chelating activity of the concentrations $0.200 \mathrm{mg} / \mathrm{mL}$ and $0.050 \mathrm{mg} / \mathrm{mL}$. The results also indicate the chelating activity of the fraction is not concentration-dependent.

Table 2. $\mathrm{Fe}^{2+}$-chelating activity of TFSR.

\begin{tabular}{|c|c|c|c|c|c|c|c|c|c|c|c|}
\hline \multirow{2}{*}{$\begin{array}{l}\text { [TFSR] } \\
\mathrm{mg} / \mathrm{mL}\end{array}$} & \multicolumn{10}{|c|}{$(\%) \mathrm{Fe}^{2+}$-Chelating Activity/Time (min) } & \multirow{2}{*}{$\begin{array}{c}\text { Asc. ac. } \\
105\end{array}$} \\
\hline & 0.5 & 2.5 & 5 & 10 & 20 & 30 & 45 & 60 & 75 & 90 & \\
\hline 0.200 & $\begin{array}{c}87.88 \pm \\
2.40\end{array}$ & $\begin{array}{c}93.61 \pm \\
1.78\end{array}$ & $\begin{array}{c}93.29 \pm \\
1.93\end{array}$ & $\begin{array}{c}92.32 \pm \\
1.75\end{array}$ & $\begin{array}{c}95.37 \pm \\
2.96\end{array}$ & $\begin{array}{c}93.37 \pm \\
3.29\end{array}$ & $\begin{array}{c}97.82 \pm \\
0.91\end{array}$ & $\begin{array}{c}95.24 \pm \\
2.69\end{array}$ & $\begin{array}{c}93.15 \pm \\
3.37\end{array}$ & $\begin{array}{c}91.86 \pm \\
3.08\end{array}$ & $\begin{array}{c}91.94 \pm \\
5.04\end{array}$ \\
\hline 0.100 & $\begin{array}{c}86.77 \pm \\
4.25\end{array}$ & $\begin{array}{c}84.55 \pm \\
2.87\end{array}$ & $\begin{array}{c}83.62 \pm \\
2.62\end{array}$ & $\begin{array}{c}85.77 \pm \\
2.81\end{array}$ & $\begin{array}{c}85.81 \pm \\
1.77\end{array}$ & $\begin{array}{c}84.44 \pm \\
4.32\end{array}$ & $\begin{array}{c}93.68 \pm \\
3.47\end{array}$ & $\begin{array}{c}86.32 \pm \\
4.11\end{array}$ & $\begin{array}{c}82.66 \# \pm \\
4.58\end{array}$ & $\begin{array}{c}79.50 \# \pm \\
2.65\end{array}$ & $\begin{array}{c}77.92 \# \pm \\
5.24\end{array}$ \\
\hline 0.050 & $\begin{array}{c}76.50 \# \pm \\
3.50\end{array}$ & $\begin{array}{c}80.92 \# \pm \\
3.39\end{array}$ & $\begin{array}{c}75.52 \# \pm \\
5.88\end{array}$ & $\begin{array}{c}75.90 \# \pm \\
4.84\end{array}$ & $\begin{array}{c}80.17 \# \pm \\
6.11\end{array}$ & $\begin{array}{c}77.49 \# \pm \\
3.73\end{array}$ & $\begin{array}{c}83.23 \# \pm \\
2.19\end{array}$ & $\begin{array}{c}76.14 \# \pm \\
3.42\end{array}$ & $\begin{array}{c}71.70 \# \pm \\
4.28\end{array}$ & $\begin{array}{c}70.85 \# \pm \\
3.02\end{array}$ & $\begin{array}{c}67.95 \# \pm \\
3.29\end{array}$ \\
\hline
\end{tabular}

These values are expressed as the means \pm SEM $(n=4)$ and analyzed by one-way ANOVA followed by Tukey's multiple comparison test, with a simple pooled variance: Significant difference $(p<0.05)$ at different timepoints and concentrations of tannic fraction of Stryphnodendron rotundifolium Mart., (TFSR). Ascorbic acid (Asc. ac.). \# Significant difference between the values of different concentrations at equal timepoints.

The rapid decrease in the absorbance of the $\mathrm{Fe}^{2+} / 0$-phe/TFSR system compared to the control (o-phe $/ \mathrm{Fe}^{2+} / \mathrm{H}_{2} \mathrm{O}$ ) indicates that the formation of chelates with $\mathrm{Fe}^{2+}$ is kinetically favored. The addition of ascorbic acid $90 \mathrm{~min}$ after the beginning of the reaction caused insignificant variation in the absorbance of the sample, revealing the generation of chelates with higher thermodynamic stability then the ferroin chelate $(\mathrm{ph})_{3} \mathrm{Fe}^{2+}$.

A study by [36] reported that the $\mathrm{Fe}^{2+}$ chelating potential of the TFSR was positively correlated with the number of catechol groups in the phenolic structures. Therefore, the abundance of highly hydroxylated proanthocyanidins with catechol and galloyl groups in the tannin-rich fraction under study offer several chelation sites, contributing to its significant $\mathrm{Fe}^{2+}$-chelating activity.

Regarding the $\mathrm{Fe}^{2+}$-chelating activity of $S$. rotundifolium, this work demonstrated that its tannin-rich fraction showed a potent effect, with fast reaction kinetics. The reaction profile indicates that the chelates formed between the fraction constituents and $\mathrm{Fe}^{2+}$ are thermodynamically more stable than the ferroin chelate of high crystal field stabilization energy (CFSE) [40]. Consequently, the authors of this work believe that the significant chelating activity of the fraction is related to synergistic effects due to the presence of prodelphinidins, prorobinetidine, and procyanidin with many catechol and galloyl groups. The potent iron-chelating activity exhibited by S. rotundifolium indicates that this species has the potential to be used to minimize oxidative effects of iron overload eating conditions that play important pathological functions, including a wide variety of disorders such as tumors, nervous system diseases, ischemia/reperfusion injury, kidney injury, and blood diseases [41].

As for the $\mathrm{Fe}^{3+}$-reducing power, at the highest concentration analyzed $(0.200 \mathrm{mg} / \mathrm{mL})$, the fraction effectively reduced $\mathrm{Fe}^{3+}$ to $\mathrm{Fe}^{2+}$ from the first timepoint of analysis (Table 3), exhibiting strong reducing activity with an average of $84 \%$ (from 0.5 to $90 \mathrm{~min}$ ) and the peak effect reached at 45 minutes, revealing the typical electron transfer characteristic of phenolic compounds [42]. Nevertheless, in this assay, the maximum activity of the fraction 
from 0.20 to $0.05 \mathrm{mg} / \mathrm{mL}$ was reached at $105 \mathrm{~min}$. The rapid decrease in the absorbance of the systems $\left(\mathrm{Fe}^{3+} / o\right.$-phe/TFSR $)$ in relation to the control $\left(o-p h e / \mathrm{Fe}^{2+} / \mathrm{H}_{2} \mathrm{O}\right)$, suggests that the reducing reaction from $\mathrm{Fe}^{3+}$ to $\mathrm{Fe}^{2+}$ is kinetically favored in the presence of the constituents of the fraction. The addition of ascorbic acid $90 \mathrm{~min}$ after the beginning of the reaction caused a decrease in the absorbance of the system $\left(\mathrm{Fe}^{3+} / o-p h e / T F S R\right)$, revealing that the $\mathrm{Fe}^{2+}$ fraction was subtracted from the ferroin chelate by the action of the TFSR, reducing the absorbance of ferroin. As observed in the iron-chelating activity experiment, no significant difference was observed with regard to the reducing activity when different timepoints at the same concentration were compared. However, there was a significant difference in $\mathrm{Fe}^{3+}$-reducing activity between the concentration of $0.200 \mathrm{mg} / \mathrm{mL}$ and the others $(0.100 \mathrm{mg} / \mathrm{mL}$ and $0.050 \mathrm{mg} / \mathrm{mL})$. The results obtained in this experiment indicate that the reducing activity responses mediated by the extract do not occur in a concentration-dependent manner.

Table 3. TFSR $\mathrm{Fe}^{3+}$-reducing activity.

\begin{tabular}{|c|c|c|c|c|c|c|c|c|c|c|c|}
\hline \multirow{2}{*}{$\begin{array}{l}\text { [TFSR] } \\
\mathrm{mg} / \mathrm{mL}\end{array}$} & \multicolumn{10}{|c|}{$(\%) \mathrm{Fe}^{3+}-$ Reducing Activity/Time (min) } & \multirow{2}{*}{$\begin{array}{c}\text { Asc. ac. } \\
105\end{array}$} \\
\hline & 0.5 & 2.5 & 5 & 10 & 20 & 30 & 45 & 60 & 75 & 90 & \\
\hline 0.200 & $\begin{array}{l}81.43 \\
\pm 2.62\end{array}$ & $\begin{array}{l}79.65 \\
\pm 4.14\end{array}$ & $\begin{array}{l}87.38 \\
\pm 1.62\end{array}$ & $\begin{array}{l}82.24 \\
\pm 4.80\end{array}$ & $\begin{array}{l}82.84 \\
\pm 5.10\end{array}$ & $\begin{array}{l}81.24 \\
\pm 4.52\end{array}$ & $\begin{array}{l}87.26 \\
\pm 3.78\end{array}$ & $\begin{array}{l}86.15 \\
\pm 2.87\end{array}$ & $\begin{array}{l}86.35 \\
\pm 3.15\end{array}$ & $\begin{array}{l}85.44 \\
\pm 4.44\end{array}$ & $\begin{array}{c}90.19 \pm \\
3.99\end{array}$ \\
\hline 0.100 & $\begin{array}{c}64.70 \# \pm \\
2.09\end{array}$ & $\begin{array}{c}64.18 \# \pm \\
5.40\end{array}$ & $\begin{array}{c}70.34 \# \pm \\
4.84\end{array}$ & $\begin{array}{c}66.10 \# \pm \\
2.53\end{array}$ & $\begin{array}{c}65.01 \# \pm \\
3.32\end{array}$ & $\begin{array}{c}62.91 \# \pm \\
4.19\end{array}$ & $\begin{array}{c}70.31 \# \pm \\
5.17\end{array}$ & $\begin{array}{c}68.58 \# \pm \\
3.39\end{array}$ & $\begin{array}{c}69.80 \# \pm \\
3 ; 06\end{array}$ & $\begin{array}{c}71.66 \# \pm \\
4.49\end{array}$ & $\begin{array}{c}77.69 \#^{*} \pm \\
3.82\end{array}$ \\
\hline 0.050 & $\begin{array}{c}61.80 \# \pm \\
2.04\end{array}$ & $\begin{array}{c}62.09 \# \pm \\
5.53\end{array}$ & $\begin{array}{c}71.83 \# \pm \\
2.39\end{array}$ & $\begin{array}{c}63.67 \# \pm \\
4.80\end{array}$ & $\begin{array}{c}65.28 \# \pm \\
4.47\end{array}$ & $\begin{array}{c}63.39 \# \pm \\
3.20\end{array}$ & $\begin{array}{c}66.65 \# \pm \\
5.06\end{array}$ & $\begin{array}{c}63.84 \# \pm \\
3.59\end{array}$ & $\begin{array}{c}63.85 \# \pm \\
2.01\end{array}$ & $\begin{array}{c}64.88 \# \pm \\
4.03\end{array}$ & $\begin{array}{c}69.01 \# \pm \\
2.79\end{array}$ \\
\hline
\end{tabular}

These values are expressed as the means $\pm \operatorname{SEM}(n=4)$ and analyzed by one-way ANOVA followed by Tukey's multiple comparison test, with a simple pooled variance: Significant difference $(p<0.05)$ at different timepoints and concentrations of TFSR. * Significant difference between the values of equal concentration. \# Significant difference between the values of different concentration at equal timepoints.

The $\bullet \mathrm{OH}$ radical-scavenging activity was evaluated using the 2-deoxyribose (2-DR) oxidative degradation method, by quantifying its main subproduct, malondialdehyde (MDA). The antioxidant activity was expressed as the percent protection of 2-DR degradation.

The hydroxyl radical $\left({ }^{\bullet} \mathrm{OH}\right)$ is a highly reactive free radical capable of triggering damage to several cellular structures. In vivo, this radical can be generated in the presence of superoxide radicals and transition cations, such as iron and copper, through the HaberWeiss reaction [43]. In the experimental conditions of this study, the $\bullet \mathrm{OH}$ radical was generated in vitro through the Fenton reaction.

Figure $4 \mathrm{~A}, \mathrm{~B}$ show the protection level exerted by the fraction when the treatment was performed previously (PT) or simultaneously (ST) to the addition of either of the prooxidant systems: $\mathrm{Fe}^{2+}$ (light-gray bars) and Fenton reaction $/{ }^{\bullet} \mathrm{OH}$ (dark-gray bars). In both treatment conditions, the fraction showed a strong protective activity against the oxidative action of $\mathrm{Fe}^{2+}$ and a moderate activity against the action of the ${ }^{\bullet} \mathrm{OH}$ radicals generated in the Fenton reaction. For the first condition, the fraction presented $\mathrm{IC}_{50}$ values of 0.0576 and $0.100 \mathrm{mg} / \mathrm{mL}$ for PT and ST, respectively. For the second condition, these values were respectively 0.225 and $0.596 \mathrm{mg} / \mathrm{mL}$. However, considering the distinct prooxidant systems, no significant difference in the protective activity of the fraction against 2-DR degradation for a given concentration was observed, indicating that the antioxidant activity was not influenced by the time of treatment.

At the concentration of $0.2 \mathrm{mg} / \mathrm{mL}$, the TFSR prevented 2-DR degradation by the pro-oxidant $\mathrm{Fe}^{2+}$ with protection levels of $72.2 \%$ and $68.6 \%$ for PT (Figure $4 \mathrm{~A}$ ) and ST (Figure 4B), respectively. However, the difference between these treatment conditions was not significant. The 2-DR degradation triggered by the ${ }^{\bullet} \mathrm{OH}$ radical generated in the Fenton reaction was inhibited by TFSR $(0.2 \mathrm{mg} / \mathrm{mL}$ ) in both PT (Figure $4 \mathrm{~A}$ ) and ST (Figure 4B) conditions, with protection levels of $42.9 \%$ and $33.1 \%$. Again, the difference between these treatment conditions was not significant.

Considering the two different oxidant systems, it can be observed that TFSR protective activity against the pro-oxidant condition $\mathrm{Fe}^{2+}$ was significantly higher that observed against ${ }^{\bullet} \mathrm{OH}$ radical produced in the Fenton reaction, as shown in Figure 4. 

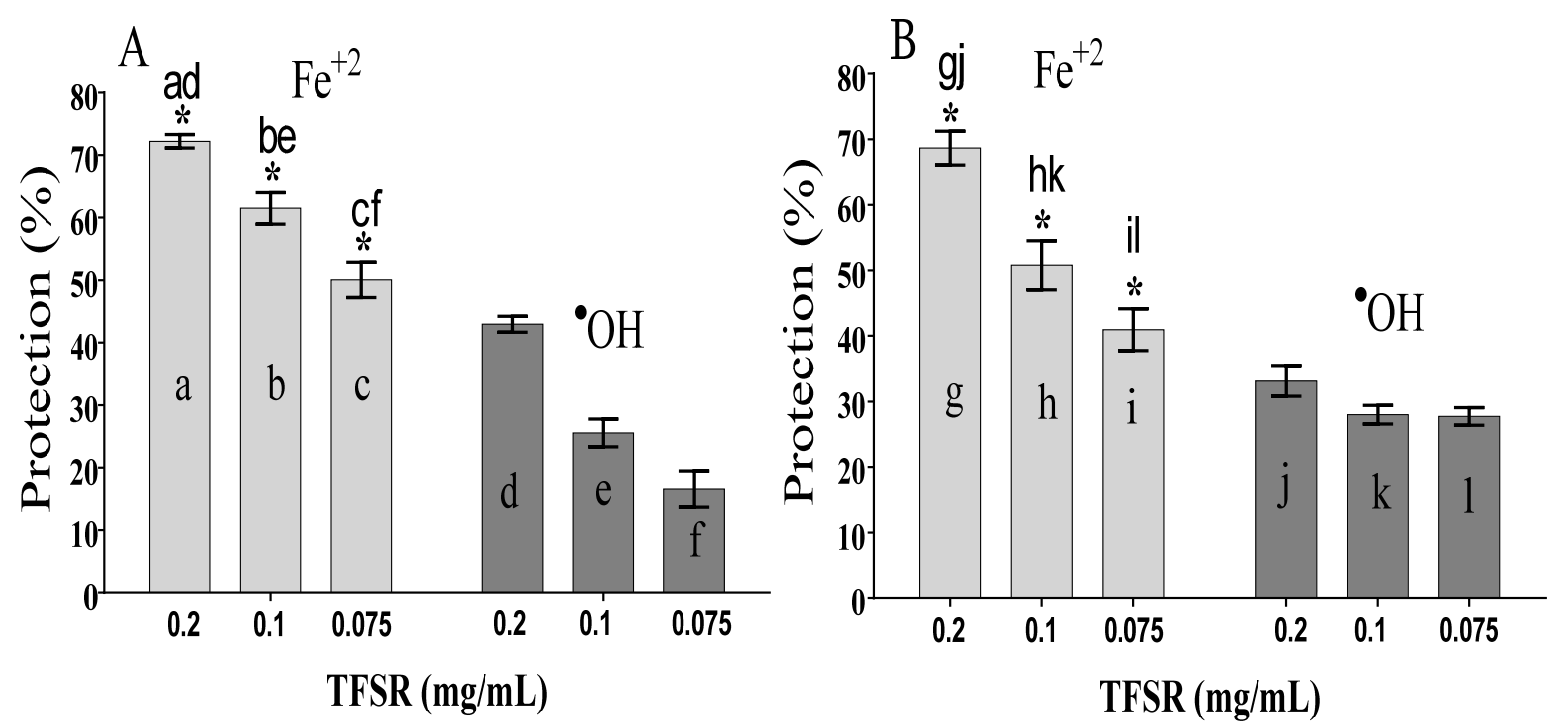

Figure 4. Percentage (\%) protection of 2-DR degradation in vitro. The antioxidant activity of the tannin-rich fraction of S. rotundifolium (TFSR) was evaluated previously (A) or simultaneously (B) to the addition of $\mathrm{Fe}^{2+}(50 \mu \mathrm{M}$, light bars) or the Fenton reaction reagents $\left(50 \mu \mathrm{M} \mathrm{Fe}^{2+}+0.5 \mathrm{mM} \mathrm{H}_{2} \mathrm{O}_{2}\right.$, dark bars). These values were expressed as the means $\pm \mathrm{SEM}$ $(n=4)$ and analyzed by one-way ANOVA followed by Tukey's multiple comparison test, with a simple pooled variance. * Significant difference $(p<0.05)$ at equal concentrations. a-l, represent the concentrations of TFSR in the different pro-oxidant systems.

The remarkable ${ }^{\bullet} \mathrm{OH}$-scavenging activity of the fraction can be attributed to the presence of hydrolyzable tannins, especially type B proanthocyanidins (dimers and trimers) with catechol and pyrogallol groups. These compounds have been recognized as excellent natural antioxidants and, as such, have the potential to be investigated in pharmacological research in several disease models [44]. Studies have indicated that the mechanism underlying the antioxidant activity of these compounds involves the donation of hydrogen and electrons responsible for the inhibition of free radicals [5,7].

To elucidate the mechanism via which the fraction protects 2-DR from degradation in the presence of the Fenton reaction, we evaluated the protective effect of different concentrations of the fraction $(0.2,0.1$, and $0.075 \mathrm{mg} / \mathrm{mL})$ using varying concentrations of 2-DR $(1.5,1.75$ and $2.0 \mathrm{mM})$ and a fixed concentration of the reacting system $\left(50 \mu \mathrm{M} \mathrm{Fe}^{2+}+\right.$ $0.5 \mathrm{mM} \mathrm{H}_{2} \mathrm{O}_{2}$ ).

The protection levels exerted by different concentrations of TFSR against 2-DR degradation did not vary significantly following the increasing 2-DR concentrations $(1.5,1.75$, and $2.0 \mathrm{mM}$ ) (Table 4), suggesting that the constituents of the fraction act predominantly as iron-chelating antioxidants, inhibiting the generation ${ }^{\bullet} \mathrm{OH}$ radicals.

Table 4. 2-DR degradation.

\begin{tabular}{cccc}
\hline & \multicolumn{3}{c}{ TFSR Protective Activity (\%) \pm SEM } \\
\hline$[2-\mathrm{DR}] \mathrm{mM}$ & $0.20 \mathrm{mg} / \mathrm{mL}$ & $0.10 \mathrm{mg} / \mathrm{mL}$ & $0.075 \mathrm{mg} / \mathrm{mL}$ \\
\hline 1.50 & $27.22 \pm 1.67$ & $21.40 \pm 1.95$ & $17.37 \pm 1.80$ \\
\hline 1.75 & $25.57 \pm 1.87$ & $21.09 \pm 3.12$ & $16.32 \pm 1.90$ \\
\hline 2.00 & $24.53 \pm 1.11$ & $19.74 \pm 0.49$ & $15.46 \pm 3.95$ \\
\hline $\begin{array}{c}\text { Statistical } \\
\text { Comparison }\end{array}$ & $\mathrm{NS}$ & $\mathrm{NS}$ & $\mathrm{NS}$ \\
\hline
\end{tabular}

These values are expressed as the means \pm SEM $(n=3)$ and analyzed by one-way ANOVA followed by multiple comparisons. Significant difference $(p<0.05)$ at equal concentrations of TFSR. NS No significant difference between the values. 
The findings of the present research indicate that the protective mechanism of TFSR occurred mainly via chelation of $\mathrm{Fe}^{2+}$ ions (as show in Table 4) and, to a lesser extent, via - $\mathrm{OH}$ radical scavenging. Importantly, this mechanism can prevent $\mathrm{Fe}^{2+}$ from participating in reactions that generate free radicals such as $\mathrm{H}_{2} \mathrm{O}_{2}$ and ${ }^{\bullet} \mathrm{OH}$, which could have beneficial roles in inhibiting oxidative stress. Nevertheless, a secondary antioxidant mechanism via - OH scavenging could contribute to the occurrence of synergistic antioxidant effects.

The preliminary toxicological analysis using $A$. salina showed that, in the range of concentrations evaluated ( 0.001 to $0.25 \mathrm{mg} / \mathrm{mL})$, mortality below $10 \%$ was observed, with no statistical difference between the rates of mortality induced by each of the tested concentrations, indicating that the fraction has low in vivo toxicity under the experimental conditions adopted in the present study (Figure 5).

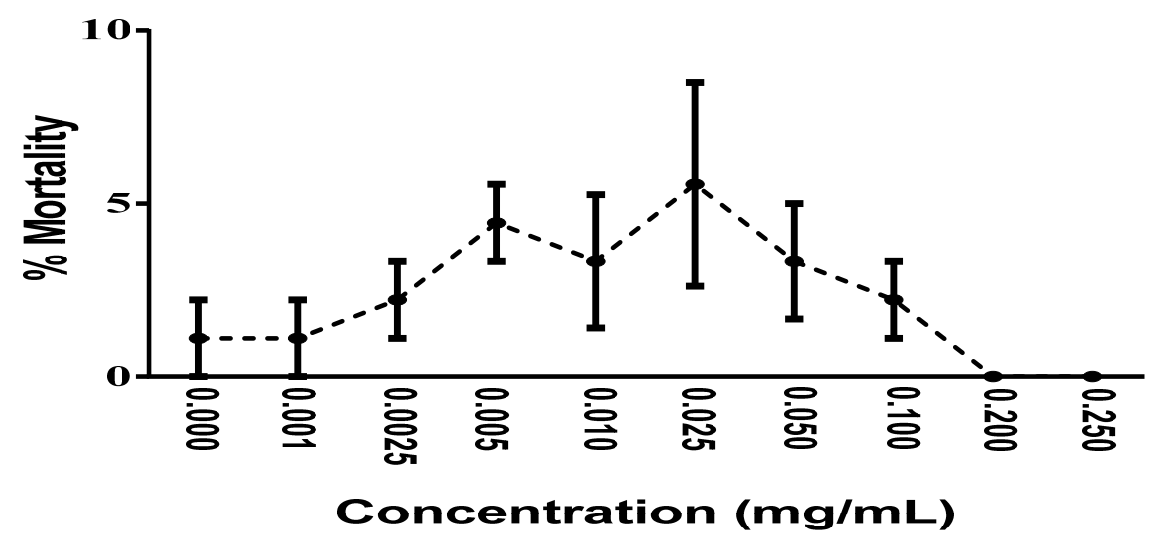

Figure 5. Artemia salina toxicity of the acetone-water fraction obtained from the stem bark of Stryphnodendron rotundifolium Mart. Mortality was analyzed $24 \mathrm{~h}$ after the addition of different fraction concentrations. These values are expressed as the means \pm SEM $(n=3)$, with a 95\% confidence interval and analyzed by nonlinear regression of the transformed curves using one-way ANOVA followed by Bonferroni correction and Tukey's multiple comparison test, with a simple pooled variance.

The results demonstrated by this preliminary toxicological evaluation suggest that the fraction can be tested in a higher concentration range, both in pharmacological and in toxicological studies, since no evident toxicity was observed at the highest tested concentration $(0.25 \mathrm{mg} / \mathrm{mL})$. However, additional studies using cell cultures and animal models are fundamental to bring relevant information regarding its in vivo safety, especially with regard to the risks associated with the ingestion of tannins.

It is hypothesized that the antioxidant effects demonstrated by the fraction are explained, at least partially, by the presence of constituents carrying pyrogallol groups containing hydroxyls capable of promoting both $\mathrm{Fe}^{3+}$ reduction and $\mathrm{Fe}^{2+}$ chelation, in addition to potentially acting as electron and hydrogen donors and, as such, acting as free-radical scavengers. The presence of galloyl portions, as well as the stabilization of phenoxyl radicals by resonance, contributes significantly to the antioxidant capacity of phenolic compounds [45]. In addition, the existence of significant amounts of galloyl portions in polyphenols favors the stabilization of phenoxyl free radicals (semiquinones), contributing to their iron-chelating and radical-scavenging activities [46].

In this context, the proanthocyanidins identified in the tannin-rich fraction present characteristics that favor their antioxidant action. In addition, these compounds can be easily absorbed by the gastrointestinal tract, which is a desirable characteristic for substances used in the development of oral drugs. Notwithstanding, proanthocyanidins with higher polymerization rates have low permeability coefficients in the human organism, impairing their oral absorption [47].

Despite the strong influence of pyrogallol and phenolic hydroxyl groups on TFSR antioxidant activity, the three-dimensional arrangement of the structure and possibly 
steric effect might contribute to the pharmacological effects of the fraction components. Thus, among the proanthocyanidins identified, we believe that dimers and trimers mostly contribute to the antioxidant activity demonstrated through 2-DR degradation protection.

Iron is a mineral with several physiological functions, found both in free form and in the composition of proteins such as hemoglobin, myoglobin, cytochromes, and several enzymes [48]. However, due its deleterious effects, the cells store free iron at low levels.

While little amounts of this mineral are commonly stored by macrophages, excess free iron reaches the circulation and deposits in hepatocytes and parenchymal cells. Iron accumulation triggers oxidative stress by mechanisms that involve the Fenton and HaberWeiss reactions. In this phenomenon, free iron acts as a catalyst for oxidative reactions stimulating the synthesis of superoxide and hydroxyl radicals [49].

Recent research has demonstrated that many of the deleterious effects of iron occur due to ferroptosis, an iron-dependent type of cell death characterized by the accumulation of lipid ROS that play important roles in a wide variety of systemic diseases, such as nervous system diseases, heart diseases, liver diseases, gastrointestinal diseases, lung diseases, kidney diseases, and pancreatic diseases [42]. Hence, the importance of demonstrating the expressive ability of TFSSR to acting as iron-chelating-reducing in vitro raises the hypothesis that this natural product may present promising results in vivo, which will be further investigated.

In fact, evidence suggests that substances capable of forming complexes with iron, thus promoting its excretion, may have applications in the treatment of several conditions [50], highlighting the therapeutic potential of S. rotundifolium, which proved to be a source of tannic compounds with $\mathrm{Fe}^{2+}$-chelating and ${ }^{\bullet} \mathrm{OH}$-scavenging activities. This hypothesis is supported by studies demonstrating that extracts with high concentrations of phenolic compounds inhibited lipid peroxidation in human erythrocytes by decreasing the production of malondialdehyde, a subproduct of 2-DR degradation [51].

In recent years, considerable interest has arisen regarding the beneficial effects of proanthocyanidins (PAs) and their monomers on human health. Studies have shown that these substances have numerous pharmacological activities, including antioxidant, anti-inflammatory, and anticancer properties [5,39,52]. Therefore, the polymeric proanthocyanidins identified in S. rotundifolium could have beneficial effects in metabolic disorders, preventing the onset of diseases whose etiology is associated with iron overload and oxidative stress [53].

\section{Conclusions}

The results of the present study demonstrated that the tannin-rich fraction of $S$. rotundifolium is a natural product with significant in vitro antioxidant activity, which may be directly related to the high content of prodelphinidins, prorobinetidines, and highly hydroxylated procyanidins with great capacity to donate electrons, as well as to chelate iron ions.

The potent $\mathrm{Fe}^{2+}$-chelating activity demonstrated by the tannin-rich fraction of $S$. rotundifolium and the significant and constant protective activity observed in the 2-DR + $\mathrm{Fe}^{2+}$ system indicate that the antioxidant mechanisms of this fraction are mainly via an ironchelating action and, to a lesser extent, an ${ }^{\bullet} \mathrm{OH}$ radical-scavenging action, at concentrations that do not cause significant toxicity in vivo in the Artemia salina model.

In conclusion, the tannic fraction of S. rotundifolium Mart. has potent antioxidant and iron-chelating activities, which indicates that it is a source of antioxidant compounds with the potential to be used in drug development in the context of iron overload disorders, which remains to be further investigated in vivo.

Author Contributions: Conceptualization, J.G.M.d.C. and G.J.T.S.; methodology, F.J.D., G.J.T.S., J.G.M.d.C. and H.D.M.C.; software, P.R.V.R., E.S.d.B. and K.M.C.; validation, G.J.T.S., P.R.V.R., E.S.d.B. and K.M.C.; formal analysis, J.G.M.d.C. and G.J.T.S.; investigation, J.G.M.d.C., H.D.M.C. and G.J.T.S.; resources, J.G.M.d.C., H.D.M.C. and G.J.T.S.; data curation, P.R.V.R., E.S.d.B. and K.M.C.; writing—original draft preparation, J.G.M.d.C. and G.J.T.S.; writing—review and editing, J.R.-F., 
M.G., D.M., D.N. and G.Z.; visualization, J.R.-F., M.G., D.M., D.N. and G.Z.; supervision, J.G.M.d.C.; project administration, J.G.M.d.C. All authors have read and agreed to the published version of the manuscript.

Funding: This research received no external funding.

Institutional Review Board Statement: Not applicable.

Informed Consent Statement: Not applicable.

Data Availability Statement: Not applicable.

Acknowledgments: This work was carried out by the Department of Biological Chemistry/Research in Natural Products of the Regional University of Cariri (URCA) with the support of the Brazilian Agency for the Coordination of Improvement of Higher Education Personnel (CAPES) and the National Council for Scientific and Technological Development (CNPq).

Conflicts of Interest: The authors declare no conflict of interest.

\section{References}

1. Ferreira Macedo, J.G.; Menezes, I.R.A.D.; Alves Ribeiro, D.; de Oliveira Santos, M.; Gonçalves de Mâcedo, D.; Ferreira Macedo, M.J.; Vilar de Almeida, B.; Souza de Oliveira, L.G.; Pereira Leite, C.; de Almeida Souza, M.M. Analysis of the variability of therapeutic indications of medicinal species in the Northeast of Brazil: Comparative study. Evid.-Based Complement. Altern. Med. 2018, 2018, 6769193. [CrossRef]

2. Ribeiro, D.A.; de Oliveira, L.G.S.; de Macêdo, D.G.; de Menezes, I.R.A.; da Costa, J.G.M.; da Silva, M.A.P.; Lacerda, S.R.; de Almeida Souza, M.M. Promising medicinal plants for bioprospection in a Cerrado area of Chapada do Araripe, Northeastern Brazil. J. Ethnopharmacol. 2014, 155, 1522-1533. [CrossRef]

3. Corrêa, M. Dicionário de Plantas Úteis do Brasil e Das Exóticas e Cultivadas; Impressa Nacional: Rio de Janeiro, Brazil, 1978.

4. Costa, J.G.M.D.; Leite, G.D.O.; Dubois, A.F.; Seeger, R.L.; Boligon, A.A.; Athayde, M.L.; Campos, A.R.; Rocha, J.B.T.D. Antioxidant effect of Stryphnodendron rotundifolium Martius extracts from Cariri-Ceará state (Brazil): Potential involvement in its therapeutic use. Molecules 2012, 17, 934-950. [CrossRef]

5. Baldivia, D.D.S.; Leite, D.F.; Castro, D.T.H.D.; Campos, J.F.; Santos, U.P.D.; Paredes-Gamero, E.J.; Carollo, C.A.; Silva, D.B.; de Picoli Souza, K.; Dos Santos, E.L. Evaluation of In Vitro Antioxidant and Anticancer Properties of the Aqueous Extract from the Stem Bark of Stryphnodendron adstringens. Int. J. Mol. Sci. 2018, 19, 2432. [CrossRef]

6. da Silveira, G.D.; Motta, M.J.; Müller, L.S.; Lameira, O.; Athayde, M.L.; Piana, M.; da Rosa, M.B.; Viana, C.; de Carvalho, L.M. Determination of phenolic antioxidants in Amazonian medicinal plants by HPLC with pulsed amperometric detection. J. Liq. Chromatogr. Relat. Technol. 2015, 38, 1259-1266. [CrossRef]

7. Fu, Y.; Qiao, L.; Cao, Y.; Zhou, X.; Liu, Y.; Ye, X. Structural elucidation and antioxidant activities of proanthocyanidins from Chinese bayberry (Myrica rubra Sieb. et Zucc.) leaves. PLoS ONE 2014, 9, e96162. [CrossRef] [PubMed]

8. Kushner, J.P.; Porter, J.P.; Olivieri, N.F. Secondary iron overload. Hematol. Am. Soc. Hematol. Educ. Program. 2001, 47-61. [CrossRef] [PubMed]

9. Phatak, P.; Brissot, P.; Wurster, M.; Adams, P.C.; Bonkovsky, H.L.; Gross, J.; Malfertheiner, P.; McLaren, G.D.; Niederau, C.; Piperno, A.; et al. A phase 1/2, dose-escalation trial of deferasirox for the treatment of iron overload in HFE-related hereditary hemochromatosis. Hepatology 2010, 52, 1671-1779. [CrossRef]

10. Nardi, G.; Cadiz, C.; Lachman, J.; Cornelio, C. Advances in hereditary hemochromatosis. Acta Gastroenterol. Latinoam. 2003, 33, 103-107, PMID. 14708503.

11. Crawford, R.D. Proposed role for a combination of citric acid and ascorbic acid in the production of dietary iron overload: A fundamental cause of disease. Biochem. Mol. Med. 1995, 54, 1-11. [CrossRef]

12. Weinberg, E.D. Cellular iron metabolism in health and disease. Drug Metab. Rev. 1990, 22, 531-579. [CrossRef]

13. Beaumont, C. Vailont, Iron homeostasis. In Disorders of iron Homeostasis, Erythrocytes, Erythropoiesis; Beaumont, C., Beris, P., Beuzard, Y., Brugnara, C., Eds.; Forum Service Editore: Genova, Italy, 2006; pp. 393-406.

14. Donovan, A.; Roy, C.N.; Andrews, N.C. The ins and outs of iron homeostasis. Physiology 2006, 21, 115-123. [CrossRef]

15. Anderson, R.L.; Wolf, W.J. Compositional changes in trypsin inhibitors, phytic acid, saponins and isoflavones related to soybean processing. J. Nutr. 1995, 125 (Suppl. 3), 581S-588S. [PubMed]

16. Awika, J.M.; Rooney, L.W.; Wu, X.; Prior, R.L.; Cisneros-Zevallos, L. Screening methods to measure antioxidant activity of sorghum (Sorghum bicolor) and sorghum products. J. Agric. Food Chem. 2003, 51, 6657-6662. [CrossRef]

17. Kaur, C.; Kapoor, H.C. Anti-oxidant activity and total phenolic content of some Asian vegetables. Int. J. Food Sci. Technol. 2002, 37, 153-161. [CrossRef]

18. Sun, T.; Ho, C.-T. Antioxidant activities of buckwheat extracts. Food Chem. 2005, 90, 743-749. [CrossRef]

19. Cadahía, E.; Conde, E.; García-Vallejo, M.; Fernández de Simón, B. High pressure liquid chromatographic analysis of polyphenols in leaves of Eucalyptus camaldulensis, E. globulus and E. rudis: Proanthocyanidins, ellagitannins and flavonol glycosides. Phytochem. Anal. 1997, 8, 78-83. [CrossRef] 
20. Cork, S.J.; Krockenberger, A.K. Methods and pitfalls of extracting condensed tannins and other phenolics from plants: Insights from investigations on Eucalyptus leaves. J. Chem. Ecol. 1991, 17, 123-134. [CrossRef]

21. Matos, F. Introduction to Experimental Phytochemical; Editions UFC: Fortaleza, Brazil, 1997.

22. Nuutila, A.M.; Puupponen-Pimiä, R.; Aarni, M.; Oksman-Caldentey, K.-M. Comparison of antioxidant activities of onion and garlic extracts by inhibition of lipid peroxidation and radical scavenging activity. Food Chem. 2003, 81, 485-493. [CrossRef]

23. Broadhurst, R.B.; Jones, W.T. Analysis of condensed tannins using acidified vanillin. J. Sci. Food Agric. 1978, 29, 788-794. [CrossRef]

24. Bossu, C.M.; Ferreira, E.C.; Chaves, F.S.; Menezes, E.A.; Nogueira, A.R.A. Flow injection system for hydrolysable tannin determination. Microchem. J. 2006, 84, 88-92. [CrossRef]

25. Andrews, N.C. Disorders of iron metabolism. N. Eng. J. Med. 1999, 341, 1986-1995. [CrossRef]

26. Burtis, C.A.; Ashwood, E.R.; Bruns, D.E. (Eds.) Tietz Textbook of Clinical Chemistry and Molecular Diagnostic, 4th ed.; Elsevier \& Saunders: St. Louis, MI, USA, 2006; pp. 797-835.

27. Worwood, M. The laboratory assessment of iron states-An update. Clin. Chim. Acta 1997, 259, 3-23. [CrossRef]

28. Zhang, D.J.; Elswick, R.K.; Miller, W.G.; Bailey, J.L. Effect of serum-clot contact time on clinical chemistry laboratory results. Clin. Chem. 1998, 44, 1325-1333. [CrossRef]

29. Minotti, G.; Aust, S.D. An investigation into thee mechanism of citrate FE ${ }^{2+}$-dependent lipid peroxidation. Free. Radic. Biol. Med. 1987, 3, 379-387. [CrossRef]

30. Gutteridge, J.M. Thiobarbituric acid-reactivity following iron-dependent free-radical damage to amino acids and carbohydrates. Febs Lett. 1981, 128, 343-346. [CrossRef]

31. Torres Salazar, G.J.; Duavy, S.M.; Adefegha, S.A.; Boligon, A.A.; Morel, A.F.; da Rocha, J.B.; Barbosa, N.B.; Ecker, A. Comparative antioxidant potential of aqueous and acetone/water extracts of grains and brans of Graniferous sorghum [Sorghum bicolor (L.) Moench] hybrid guanipa 71 in vitro. Int. J. Pharm. Sci. Res. 2018, 9, 932-944.

32. McLaughlin, J. Brine shrimp: A convenient general bioassay for active constituents. Planta Med. 1982, 45, 31-32.

33. Henriques, B.O.; Corrêa, O.; Azevedo, E.P.C.; Pádua, R.M.; Oliveira, V.L.S.D.; Oliveira, T.H.C.; Boff, D.; Dias, A.C.F.; Souza, D.G.D.; Amaral, F.A. In vitro TNF-inhibitory activity of brazilian plants and anti-inflammatory effect of Stryphnodendron adstringens in an acute arthritis model. Evid. Based Complement. Altern. Med. 2016, 2016, 9872598. [CrossRef] [PubMed]

34. de Mello, J.P.; Petereit, F.; Nahrstedt, A. Flavan-3-ols and prodelphinidins from Stryphnodendron adstringens. Phytochemistry 1996, 41, 807-813. [CrossRef]

35. Pinto, S.C.G.; Bueno, F.G.; Panizzon, G.P.; Morais, G.; Dos Santos, P.V.P.; Baesso, M.L.; de Souza Leite-Mello, E.V.; de Mello, J.C.P. Stryphnodendron adstringens: Clarifying wound healing in streptozotocin-induced diabetic rats. Planta Med. 2015, 81, 1090-1096. [CrossRef] [PubMed]

36. Demarque, D.P.; Callejon, D.R.; de Oliveira, G.G.; Silva, D.B.; Carollo, C.A.; Lopes, N.P. The role of tannins as antiulcer agents: A fluorescence-imaging based study. Rev. Bras. Farmacogn. 2018, 28, 425-432. [CrossRef]

37. Li, H.-J.; Deinzer, M.L. Tandem mass spectrometry for sequencing proanthocyanidins. Anal. Chem. 2007, 79, 1739-1748. [CrossRef]

38. Robeson, D.J.; Ingham, J.L.; Harborne, J.B. Identification of two chromone phytoalexins in the sweet pea, Lathyrus odoratus. Phtochemistry 1980, 19, 2171-2173.

39. Bladé, C.; Aragonès, G.; Arola-Arnal, A.; Muguerza, B.; Bravo, F.I.; Salvadó, M.J.; Arola, L.; Suárez, M. Proanthocyanidins in health and disease. Biofactors 2016, 42, 5-12. [PubMed]

40. Shriver, D.F.; Atkins, P.W. Inorganic Chemistry, 3rd ed.; Bookman: Porto Alegre, Brazil, 2003.

41. Li, J.; Cao, F.; Yin, H.-L.; Huang, Z.-J.; Lin, Z.-T.; Mao, N.; Sun, B.; Wang, G. Ferroptosis: Past, present and future. Cell Death Dis. 2020, 11, 1-13. [CrossRef]

42. Leopoldini, M.; Marino, T.; Russo, N.; Toscano, M. Antioxidant properties of phenolic compounds: H-atom versus electron transfer mechanism. J. Phys. Chem. A 2004, 108, 4916-4922. [CrossRef]

43. Castro, L.; Freeman, B.A. Reactive oxygen species in human health and disease. Nutrition 2001, 17, 161-165. [CrossRef]

44. Macáková, K.; Kolečkář, V.; Cahlíková, L.; Chlebek, J.; Hošt'álková, A.; Kuča, K.; Jun, D.; Opletal, L. Tannins and their influence on health. In Recent Advances in Medicinal Chemistry; Elsevier: Amsterdam, The Netherlands, 2014; pp. 159-208.

45. Zhao, X.; Sun, H.; Hou, A.; Zhao, Q.; Wei, T.; Xin, W. Antioxidant properties of two gallotannins isolated from the leaves of Pistacia weinmannifolia. Biochim. Biophys. Acta 2005, 1725, 103-110. [CrossRef]

46. Guo, Q.; Zhao, B.; Shen, S.; Hou, J.; Hu, J.; Xin, W. ESR study on the structure-antioxidant activity relationship of tea catechins and their epimers. Biochim. Biophys. Acta (BBA)-Gen. Subj. 1999, 1427, 13-23. [CrossRef]

47. Ou, K.; Gu, L. Absorption and metabolism of proanthocyanidins. J. Funct. Foods 2014, 7, 43-53. [CrossRef]

48. Manjunatha, H.; Srinivasan, K. Protective effect of dietary curcumin and capsacin on induced oxidation of low-density lipoprotein, iron-induced hepatotoxicity and carrageenan-induced inflammation in experimental rats. FEBS J. 2006, 273, 4528-4537. [CrossRef] [PubMed]

49. Santos, P.C.; Cançado, R.D.; Terada, C.T.; Guerra-Shinohara, E.M. Alterações moleculares associadas à hemocromatose hereditária. Rev. Bras. Hematol. Hemoter. 2009, 31, 192-202. [CrossRef]

50. Birch, N.; Wang, X.; Chong, H.-S. Iron chelators as therapeutic iron depletion agents. Expert Opin. Ther. Pat. 2006, 16, 1533-1556. [CrossRef] 
51. Lopes, R.H.O.; Macorini, L.F.B.; Antunes, K.Á.; Espindola, P.P.D.T.; Alfredo, T.M.; Rocha, P.D.S.D.; Pereira, Z.V.; Santos, E.L.D.; de Picoli Souza, K. Antioxidant and hypolipidemic activity of the hydroethanolic extract of Curatella americana L. leaves. Oxidative Med. Cell. Longev. 2016, 2016, 9681425. [CrossRef]

52. Kaplum, V.; Ramos, A.C.; Consolaro, M.E.; Fernandez, M.A.; Ueda-Nakamura, T.; Dias-Filho, B.P.; Silva, S.D.O.; de Mello, J.C.; Nakamura, C.V. Proanthocyanidin polymer-rich fraction of Stryphnodendron adstringens promotes in vitro and in vivo cancer cell death via oxidative stress. Front. Pharmacol. 2018, 9, 694. [CrossRef]

53. Smeriglio, A.; Barreca, D.; Bellocco, E.; Trombetta, D. Proanthocyanidins and hydrolysable tannins: Occurrence, dietary intake and pharmacological effects. Br. J. Pharmacol. 2017, 174, 1244-1262. [CrossRef] [PubMed] 